\title{
The 1988 Excavations at Tell Sabi Abyad, a Later Neolithic Village in Northern Syria
}

\author{
PETER M.M.G. AKKERMANS AND MARIE LE MIÈRE
}

\begin{abstract}
The site of Tell Sabi Abyad in the upper Balikh valley of northern Syria is one of the focal points of excavation of a regionally oriented research project, aimed at clarifying the chronology, settlement organization, and ecology of later Neolithic society in the region. So far the emphasis of fieldwork has been on the Halaf period, i.e., the later sixth and early fifth millennium B.C. The second season of excavation (1988) at Tell Sabi Abyad, one of the largest Halaf settlements in the region, provided insight into the origins of Halaf, well supported by a series of 12 radiocarbon dates. The absence of a stratigraphic break points toward a continuous and uninterrupted sequence of occupation, with Halaf gradually emerging out of an earlier, locally founded Neolithic tradition. A major innovation was the introduction of finely textured and busily painted ceramics around 5200 B.C., some of which display clear Samarran stylistic traits. The excavations have yielded a detailed picture of Halaf settlement layout in its earliest days. Over $800 \mathrm{~m}^{2}$ have been investigated in broad horizontal exposures, showing evidence of a loose aggregation of multiroomed (and possibly multistoried) rectilinear buildings, surrounded by subsidiary annexes and circular structures. The role of a huge stone retaining wall remains enigmatic; most likely this wall supported a large terrace, the function of which is still unknown.*
\end{abstract}

\section{INTRODUCTION}

Ever since Sir Max Mallowan's excavations at the site of Arpachiyah in Iraq in the early 1930s, the prehistoric Halaf culture has had the connotation of brilliantly painted pottery, round buildings (tholoi), and a variety of characteristic beads, amulets, and figurines spread over a vast region within a presum-

\footnotetext{
* We wish to express our gratitude to the Directorate General of Antiquities and Museums of the Syrian Arab Republic for its continued assistance and encouragement concerning the excavations at Tell Sabi Abyad; our thanks go to Ali Abu Assaf, Adnan Bounni, Murhaf al-Khalaf, Mohammad Muslim, and Mohammad Maktash.

1 M.E.L. Mallowan and J.C. Rose, "Excavations at Tell Arpachiyah, 1933," Iraq 2 (1935) 1-178; A.L. Perkins, The Comparative Archaeology of Early Mesopotamia (Chicago 1949); S.A. LeBlanc and P.J. Watson, "A Comparative Statistical Analysis of Painted Pottery from Seven Halafian Sites," Paléorient 1 (1973) 117-33; J. Mellaart, The Neolithic of the Near East (London 1975); T.E. Davidson, Regional Variation within the Halaf Ceramic Tradition (Edinburgh 1977); I.M. Hijara, The Halaf Period in Northern Mesopotamia (London 1980); C. Gustavson-Gaube, "Shams ed-Din Tannira: The Halafian Pottery of Area A," Berytus 29 (1981) 9-182; P.J. Watson, "The Soundings at Banahilk," in L.S.
}

ably rather short period of time and in a more or less uniform manner. ${ }^{1}$ The rain-fed plains of northern Iraq are commonly considered to be the homelands of Halaf society, and the unparalleled wide distribution of Halaf traits around 5000 B.C. (from the Zagros Mountains in the east to the border of Anatolia in the west) is for some regions attributed to the migration or movement of Halaf populations, ${ }^{2}$ whereas for other areas trade or diffusion of Halafian traits is thought to be a more appropriate explanation. ${ }^{3}$ When compared with the earlier stages of the Neolithic of the Near East, increasing social interaction and an increasingly complex society are commonly assumed for the later sixth and fifth millennium. ${ }^{4}$ Whereas some suggest that Halaf society was organized at the level of tribes, ${ }^{5}$ others assume some sort of chiefdom. ${ }^{6}$

In spite of over 50 years of research on the Halaf period, however, serious deficiencies in the understanding of Halaf society occur at virtually every level of investigation. Not only are the origins and chronology of Halaf society poorly understood, but interpretations of economic or social organization rarely go beyond the level of sheer speculation. Any insight into the Halaf phenomenon is severely restricted by the fragmentary or biased nature of our present data. The main reasons that account for this limited understanding are 1) only little research has been undertaken focusing on Halaf society (in most cases Halaf material has been the accidental by-product of fieldwork pursuing other objectives); 2) vast regions of the

Braidwood et al., Prehistoric Archeology along the Zagros Flanks (Chicago 1983) 545-613; P.J. Watson, "The Halafian: A Review and Synthesis," in T. Young, P. Smith, and P. Mortensen eds., The Hilly Flanks and Beyond (Chicago 1983); and P.J. Watson and S.A. LeBlanc, Girikihaciyan-A Halafian Site in Southeastern Turkey (Los Angeles 1990).

2 Davidson (supra n. 1).

3 Perkins (supra n. 1) 44-45; R.J. Braidwood and L.S. Braidwood, Excavations in the Plain of Antioch (Chicago 1960) 137; J. Mellaart, "The Earliest Settlements in Western Asia from the Ninth to the End of the Fifth Millennium B.C.," CAH I (1970) 277; I. Thuesen, Hama: The Pre- and Protohistoric Periods (Copenhagen 1988) 187.

${ }^{4}$ C.L. Redman, The Rise of Civilization (San Francisco 1978) 199.

${ }^{5}$ Hijara (supra n. 1).

${ }^{6}$ LeBlanc and Watson (supra n. 1); Watson, in Young et al. (supra n. 1); Watson and LeBlanc (supra n. 1). 


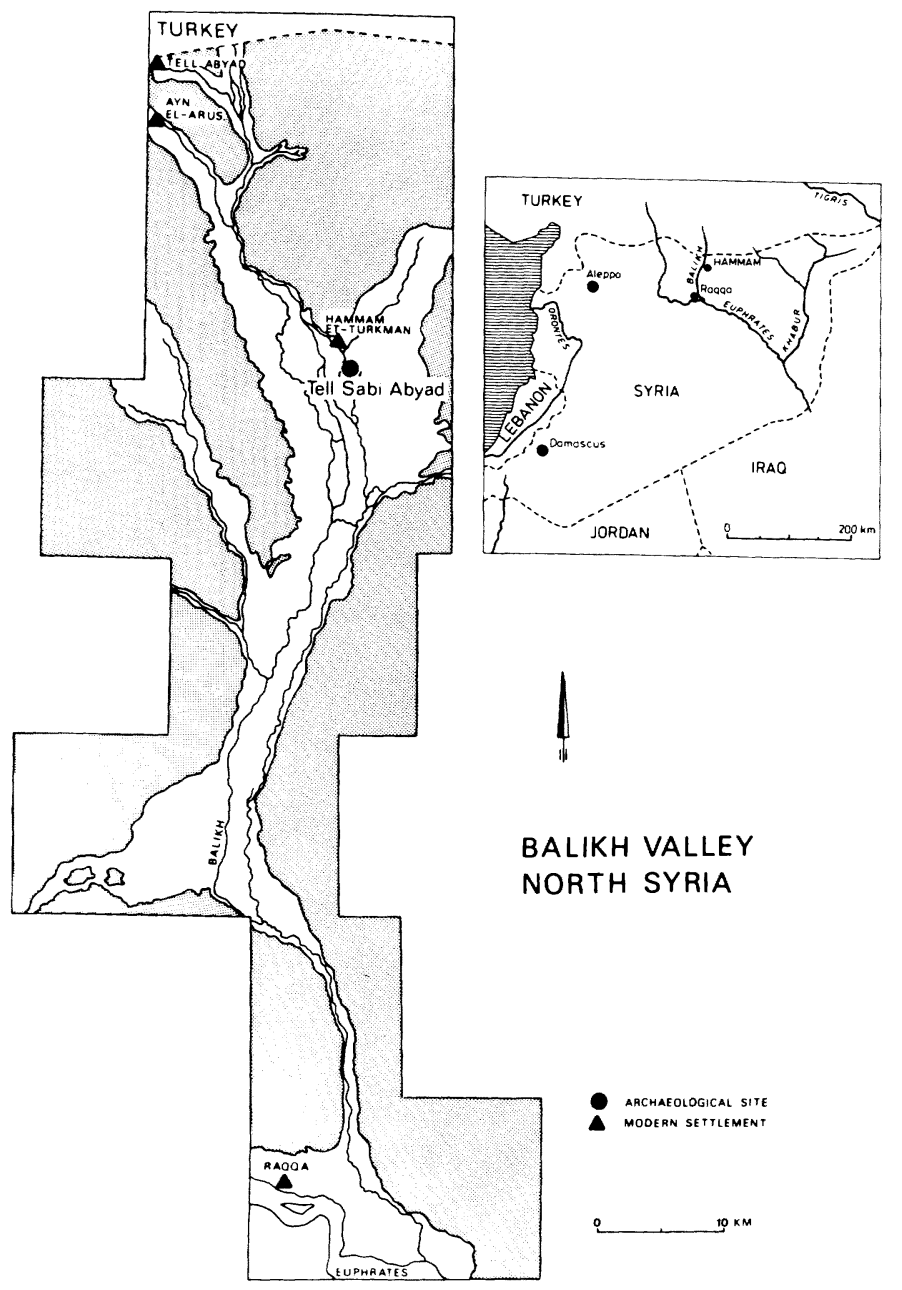

Fig. 1. Map of the Balikh valley and the location of Tell Sabi Abyad

Near East have hardly been investigated; and 3) fieldwork is in most cases site-oriented, thereby largely neglecting any regional, intersite relationships and variability. In addition, our present knowledge is onesided and distorted because of an emphasis of excavation upon larger mounds with long sequences; until recently, small, short-term settlements hardly received attention.

In the light of the above, a regionally oriented research project was initiated, focusing on the chronology, settlement organization, and ecology of Halaf society in the Balikh valley of northern Syria, a wellcircumscribed and ecologically and geographically more or less homogeneous region littered with pre-

\footnotetext{
${ }^{7}$ For a general introduction to the site and an account of the first season's results, see the following works by P.M.M.G. Akkermans: "A Late Neolithic and Early Halaf Village at Sabi Abyad, Northern Syria," Paléorient 13 (1987) 23-40; "Tell Sabi Abyad: Preliminary Report on the 1986
}

historic sites. A combined program of survey and excavation was set up, and several sites of various size, date, and, presumedly, function were chosen for excavation. One of these is Tell Sabi Abyad, located in the northern part of the Balikh valley, about $2 \mathrm{~km}$ south of the modern village of Hammam et-Turkman (fig. 1). The site measures about $240 \times 170 \mathrm{~m}$ at its base (about $4.1 \mathrm{ha}$ ) and rises between 5 and $10 \mathrm{~m}$ above the surrounding fields.

Excavation at Tell Sabi Abyad was started in the spring of 1986. This first campaign showed that Sabi Abyad was a major prehistoric settlement, mainly belonging to the later sixth millennium. ${ }^{7}$ In the autumn of 1988, excavation was continued in the areas ex-

Excavations," Akkadica 52 (1987) 10-28; "The Neolithic of the Balikh Valley, Northern Syria: A First Assessment," $P a$ léorient 15:1 (1989) 121-33; and Akkermans ed., Excavations at Tell Sabi Abyad-Prehistoric Investigations in the Balikh Valley, Northern Syria (Oxford 1989). 


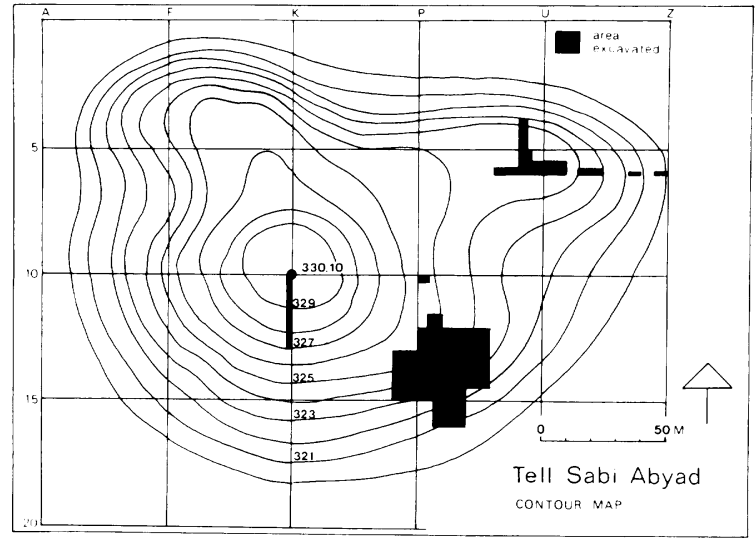

Fig. 2. Contour map of Tell Sabi Abyad with the areas of excavation indicated

plored during the first season and, additionally, new trenches were opened in the northeastern and southeastern parts of the site as well as on the top of the mound (fig. 2). Archaeological work concentrated on occupation levels of the Early Halaf period (ca. 52005000 B.C., uncalibrated), of which over $800 \mathrm{~m}^{2}$ have so far been unearthed in broad horizontal exposures and which have yielded an insight into Halaf settlement organization and developments in the use of space. These horizontal excavations were conducted primarily in $9 \times 9 \mathrm{~m}$ squares, but in many cases the squares were divided into smaller units during excavation for better stratigraphic and/or horizontal control. Earlier strata of settlement were sampled on a limited scale in various stepped-trench operations. Deposits from a selected number of floors, rooms, hearths, etc., were sieved and/or flotated. Well-preserved Halaf strata appeared immediately below the surface of the mound; only in the westernmost trenches of the southeastern area were the topmost prehistoric levels partly disturbed by late second millennium building activities. ${ }^{8}$

The excavations yielded a complex sequence, over $3 \mathrm{~m}$ deep, of Early Halaf levels, differing in many respects from that established at other sites. Tell Sabi Abyad is not one coherent mound but a cluster of at least four small mounds that have merged in the course of time; the excavations showed evidence of a loose aggregation of one or two large rectangular buildings on the top of each mound, surrounded along the slopes by rectangular annexes and numerous tholoi. It therefore seems that the Halafian com-

8 P.M.M.G. Akkermans and I. Rossmeisl, "Excavations at Tell Sabi Abyad, Northern Syria: A Regional Centre on the Assyrian Frontier," Akkadica 66 (1990) 13-60.

${ }^{9}$ Extensive case studies by various persons are awaited. munity as a whole consisted of only four or five extended house complexes or households, together perhaps comprising a population of 30 to 50 individuals. In general, the prehistoric site does not seem to have been densely settled.

One of the most significant finds was the discovery of earlier Neolithic occupation levels, immediately preceding the occurrence of Halaf at the site. No gap in occupation is indicated and Halaf at Sabi Abyad was apparently the result of a gradual and continuous local process of cultural change. So far, no other excavated site has provided a similar transitional sequence, as all other investigated sites were newly founded during the Halaf period.

The main area chosen for excavation was the relatively low southeastern portion of Sabi Abyad, but in addition a number of small operations were carried out on the top and in the northeastern part of the site. The results of the various soundings are summarized below; the emphasis is upon stratigraphy and architecture, and upon related ceramic developments. ${ }^{9}$

\section{EXCAVATIONS ON THE SOUTHEASTERN MOUND}

The stratigraphic sequence on the southeastern mound of Tell Sabi Abyad strongly varied from trench to trench, due to a differential use of space for various activities. In each square of excavation, a number of strata and substrata were recognized, ${ }^{10}$ regrouped here into eight main phases or "levels" of occupation. These levels emphasize the overall relationships between the various trenches and delineate coherent building phases. The earliest levels (8-7) belong to a pre-Halaf Neolithic phase of occupation (ca. 5300-5200 B.C., uncalibrated), whereas the subsequent three levels (6-4) are part of a transitional stage (ca. 5200-5100) between the earlier Neolithic and the "Early Halaf" period (ca. 5100-5000), represented by levels 3-1. A series of radiocarbon dates firmly supports the present sequence (table 1).

\section{THE PRE-HALAF NEOLITHIC: LEVELS 8-7}

\section{Stratigraphy and Architecture}

Levels 8-7 (and, in addition, level 6) have been reached only in a narrow trench (P15) $9 \mathrm{~m}$ long and $2 \mathrm{~m}$ wide along the southern slope of the southeastern mound. Judging from the ceramic assemblage and

These reports will deal in detail with stratigraphy, architecture, pottery, lithic industry, faunal and floral remains, etc.

10 P.M.M.G. Akkermans, "Tell Sabi Abyad: Stratigraphy and Architecture," in Akkermans ed. (supra n. 7) 17-75. 
Table 1. Radiocarbon Dates from Tell Sabi Abyad

\begin{tabular}{|c|c|c|c|c|c|}
\hline Lab. No. & Material & Level & $\begin{array}{c}\text { Conven- } \\
\text { tional } \\
\text { Date B.P. }\end{array}$ & $\begin{array}{c}\text { Conven- } \\
\text { tional } \\
\text { Date B.C. }\end{array}$ & $\begin{array}{l}\text { Calibra- } \\
\text { ted } \\
\text { Date B.C. }\end{array}$ \\
\hline GrN-16804 & burnt grain & 1 & $6975 \pm 30$ & $5025 \pm 30$ & $5951-5768$ \\
\hline GrN-16800 & charcoal & 2 & $7005 \pm 30$ & $5055 \pm 30$ & $5959-5818$ \\
\hline GrN-16801 & burnt seeds & 3 & $7465 \pm 35$ & $5515 \pm 35$ & $6390-6189$ \\
\hline GrN-16802 & burnt seeds & 3 & $7065 \pm 30$ & $5115 \pm 30$ & $5977-5818$ \\
\hline GrN-16803 & burnt seeds & 4 & $7075 \pm 25$ & $5125 \pm 25$ & $5979-5889$ \\
\hline UtC- 1008 & charcoal & 4 & $6930 \pm 80$ & $4980 \pm 80$ & 5954-5664 \\
\hline UtC-1009 & burnt seeds & 8 & $7080 \pm 80$ & $5130 \pm 80$ & $6074-5883$ \\
\hline GrN-16805 & burnt wood & 8 & $7145 \pm 30$ & $5195 \pm 30$ & $6077-5976$ \\
\hline UtC-1010 & burnt wood & $\begin{array}{l}\text { (Halaf NE } \\
\text { mound) }\end{array}$ & $6670 \pm 100$ & $4720 \pm 100$ & $5640-5480$ \\
\hline UtC-1011 & burnt wood & $\begin{array}{l}\text { (pre-Halaf NE } \\
\text { mound) }\end{array}$ & $7150 \pm 90$ & $5200 \pm 90$ & $6090-5960$ \\
\hline UtC-1012 & charcoal & $\begin{array}{l}\text { (pre-Halaf NE } \\
\text { mound) }\end{array}$ & $7170 \pm 90$ & $5220 \pm 90$ & $6100-5970$ \\
\hline GrN-16806 & charcoal & $\begin{array}{l}\text { (pre-Halaf NE } \\
\text { mound) }\end{array}$ & $7225 \pm 30$ & $5275 \pm 30$ & $6097-6003$ \\
\hline
\end{tabular}

radiocarbon dates, these earliest levels are closely related to those exposed on the northeastern part of Tell Sabi Abyad and date from around 5300 B.C. Virgin soil has not yet been reached, despite the fact that the lowest strata unearthed were already almost $2 \mathrm{~m}$ below the level of the surrounding fields. Apparently, the surroundings of the site have witnessed a considerable accumulation of aeolic-fluviatile deposits in the course of time, which hid part of the mound from view. ${ }^{11}$

Level 8 represents the earliest phase of occupation so far excavated in trench P15. This level consisted of a ca. $60-\mathrm{cm}$ thick accumulation of alternately grayblack and red-brown layers, intermingled with ash lenses, charcoal particles, and cobbles, and sloping toward the southeast. In the northwestern corner of trench P15 these sloping layers were laid against a feature of rectangular shape, perhaps a pisé wall.

The lower level 8 remains were covered by a 5-6 $\mathrm{cm}$ thick surface of gray-brown clay upon which various mudbrick walls were erected: level 7 . The walls have been preserved to a height of about $80-90 \mathrm{~cm}$ and are built up of mudbricks ca. $40 \mathrm{~cm}$ wide and 5$6 \mathrm{~cm}$ thick (the length could not be established). Parts of two multiroomed buildings were unearthed, built against each other. At a certain time, the rooms filled in with mudbrick debris and layers of red-brown or gray-black ashy soil. The architectural features and

\footnotetext{
11 P.M.M.G. Akkermans, Villages in the Steppe-Later Neolithic Settlement and Subsistence in the Balikh Valley, Northern Syria (Amsterdam 1990) 144-47.
}

associated room fill were covered by a ca. 40 -cm thick layer of soft, gray-brown soil, intermingled with ashy spots, charcoal, and cobbles, and sloping toward the southeast. Large quantities of bone and sherds were found in this layer of local erosion.

\section{The Pottery}

The vast bulk (ca. 95\% of the total sherd count) of the level 8-7 pottery can be described as plant-tempered and often burnished Coarse ware. ${ }^{12}$ The pottery shows only a little variety in shape and mainly consists of simple, plain-rim bowls with a rounded or occasionally straight vessel wall, hole-mouth pots, and jars generally with low necks. A few "husking-tray" fragments were found, with shallow ridges or fingerimpressed pits on their interior bases. These trays comprise the only vessel shape truly comparable to ceramics found further east (northern Mesopotamia); in virtually all other respects the pre-Halaf Neolithic pottery of Sabi Abyad shows strong ties with the assemblages of western sites of the sixth millennium (particularly with the Amuq). Husking trays remained in use in small quantities throughout the prehistoric occupation of the southeastern mound.

In the lowest level about $6 \%$ of the Coarse ware products (mainly bowls) are red-burnished. Similar pottery was also found in the subsequent levels, although in ever-decreasing quantities, until it finally

\footnotetext{
${ }^{12}$ For terminology, see P.M.M.G. Akkermans, "The Prehistoric Pottery of Tell Sabi Abyad," in Akkermans ed. (supra n. 7) $81-82$.
} 
disappeared in level 5. Less than $1 \%$ of the Coarse ware ceramics have incised or impressed patterns of crosshatching, oblique lines, and herringbone, whereas another $2 \%$ have bands of dark-red paint, occasionally in combination with incision. Most of the decorated fragments seem to have been parts of jars.

Locally manufactured Gray-Black ware and imported Dark-faced Burnished ware ${ }^{13}$ account for hardly $5 \%$ of the total sherd bulk. These rather thinwalled and smoothed wares were much more carefully finished than the Coarse ware. Shapes are again simple and consist mainly of small bowls and anglenecked jars. The gray pottery occasionally has whitefilled incisions whereas some Dark-faced Burnished pots have broad bands of dark-red paint upon a highly burnished, black surface. That this pottery was highly valued is suggested by the repeatedly observed traces of repair: jars with apparently damaged necks had been transformed into hole-mouth pots by entirely removing the neck and subsequently grinding the break.

\section{THE TRANSITIONAL PERIOD: LEVELS 6-4}

\section{Stratigraphy and Architecture}

Level 6 is characterized by parts of two rectangular structures built against each other. The new buildings, partly preserved to a height of $1.0-1.1 \mathrm{~m}$, were constructed of long but thin mudbricks measuring $40-50 \times 40 \times 6-8 \mathrm{~cm}$. After the raising of the walls, a mud floor ca. $4-6 \mathrm{~cm}$ thick was laid in the various rooms.

Finally the rooms were filled in with mudbrick fragments and other domestic debris and were subsequently covered by a ca. 1.5-m thick layer of redburnt soil and dark ashes. This deposit is rather homogeneous in nature although some stratigraphy is indicated. The lower walls were heavily affected by fire, which penetrated the walls throughout. Although it can be argued that this layer suggests a violent destruction of the level 6 settlement, this possibility can be rejected on stratigraphic grounds (fill of rooms, thick layer of ashes covering the wall remnants, and the fact that some ash layers begin at a high elevation above the walls) and on the basis of finds in the ash deposits above the walls (large numbers of sherds and bones, basalt ground tools, and a large, rectangularly hewn stone).

After leveling the level 6 layer of ashes and burnt soil, the site inhabitants erected new architecture:

${ }^{13}$ Apart from a close resemblance in shape and finish to the Amuq Dark-faced Burnished ware, a clay analysis made clear that this pottery indeed stemmed from western Syria or Cilicia; cf. M. Le Mière, "Clay Analyses of the Prehistoric

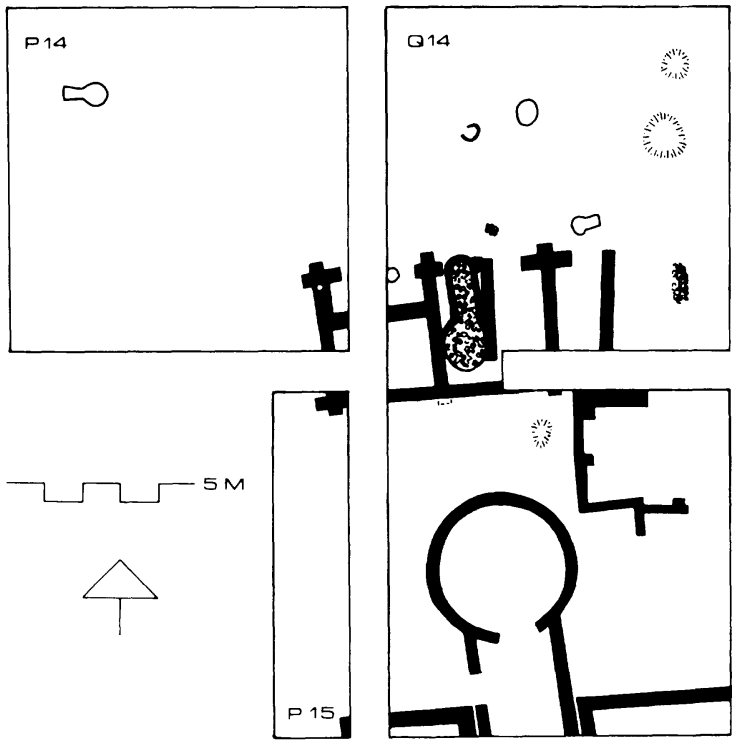

Fig. 3. Plan of level 4 architecture in the southernmost squares of excavation

level 5. In the northern corner of trench P15, parts of two walls were found, perpendicular to each other and bounding a room that had been traced earlier in square P14. ${ }^{14}$ Both walls were ca. $20 \mathrm{~cm}$ wide and preserved to a height of $60-90 \mathrm{~cm}$. The floor was characterized by a gray mud plaster, ca. $5 \mathrm{~cm}$ thick, whereas the walls were covered by a ca. 1-cm thick orange mud plaster, in its turn coated by a thin white layer. The room interior was filled with orange-brown soil and fragments of wall plaster. After the building had gone out of use, layers of mudbrick debris and compact gray or brown soil accumulated to a height of $0.6-1.0 \mathrm{~m}$.

Remains of the overlying level, level 4 , were traced over an area of about $400 \mathrm{~m}^{2}$ and, apart from P15, can be related to the lowest strata reached in the southern squares-P14, Q14, and Q15-and, most likely, also to those of the northern squares-P12 and Q12. The intermediate squares, P13 and Q13, separating the northern trenches from the southern ones, await further excavation (here level 3 building remains are still standing to a considerable height) and therefore permit no direct, unambiguous correlation.

In the southern squares, a small rectangular building of mudbricks appeared, founded simply on earth and partially supported by buttresses on the edges (fig. 3). The building was about $8.2 \mathrm{~m}$ long and $3.6 \mathrm{~m}$

Pottery: First Results," in Akkermans ed. (supra n. 7) 23335.

14 Akkermans (supra n. 10) 25. 


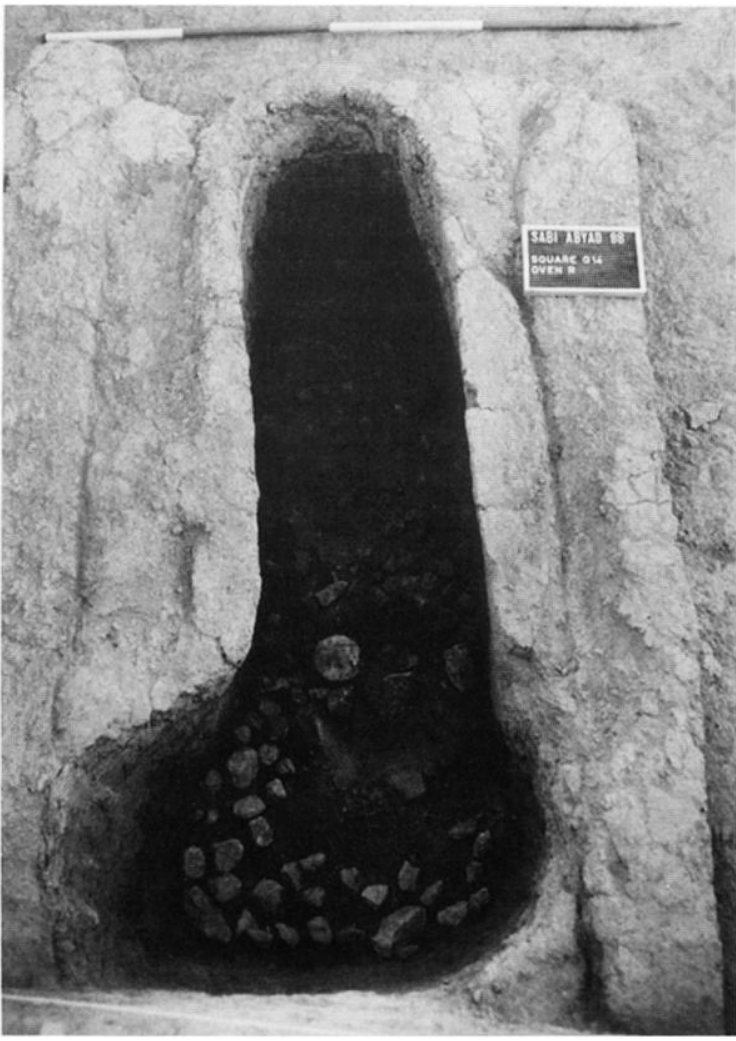

Fig. 4. Keyhole-shaped kiln with mudbrick lining, sunk into the floor of level 4 building in square Q14 (view from south)

wide and consisted of a series of narrow rooms, each measuring about $3.3 \times 1.2-1.3 \mathrm{~m}$. The westernmost room was divided into two smaller units, measuring
$2.5 \times 1.0$ and $2.5 \times 1.8 \mathrm{~m}$ respectively. All main rooms were individually accessible from the north through entrances about $70-80 \mathrm{~cm}$ wide. Additional access to the smaller units is suggested by a small, tapering pivot hole in the western support wall. ${ }^{15}$

In one of the rooms, a large keyhole-shaped kiln was partly sunk to a depth of $80 \mathrm{~cm}$ into the floor (fig. 4). The narrow but elongated apsidal part (about $1.6 \mathrm{~m}$ long and $0.6 \mathrm{~m}$ wide) probably served as the combustion chamber, whereas the roughly circular part represents the heating chamber (ca. $1 \mathrm{~m}$ in diameter). The latter was partly filled with blackened and heat-cracked stones, also found at floor level in the combustion chamber. At least the combustion chamber seems to have had a superstructure of mudbricks, curving in toward the top and creating a dome. The heating chamber was probably open. The kiln interior had a mud plaster that showed only superficial traces of firing; apparently, the temperatures reached in this kiln were not very high. Earlier, two identical kilns were found in level $2,{ }^{16}$ although these stood simply in the open air.

South of the rectangular building, a large tholos of an unusual type at Sabi Abyad appeared (fig. 3). The building is well preserved, with walls still standing to a height of about $70 \mathrm{~cm}$ (figs. 5-6). The structure consists of two rooms, one circular and one rectangular (with bonded walls). Both the interior and exterior wall faces are covered with a gray mud plaster, ca. $2.5 \mathrm{~cm}$ thick. The circular room has an interior diameter of $3.25 \mathrm{~m}$, whereas the antechamber has a width of $2 \mathrm{~m}$ and a length of at least $3 \mathrm{~m}$ (the exact

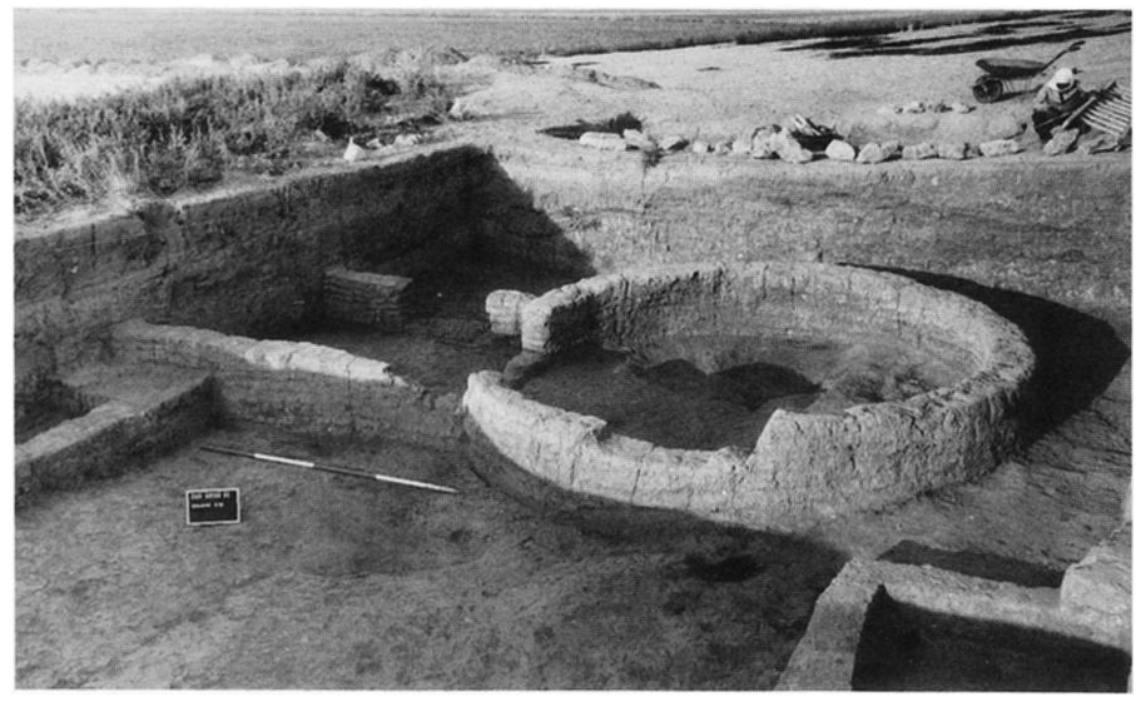

Fig. 5. Keyhole-shaped tholos in square Q15 (view from northeast) 


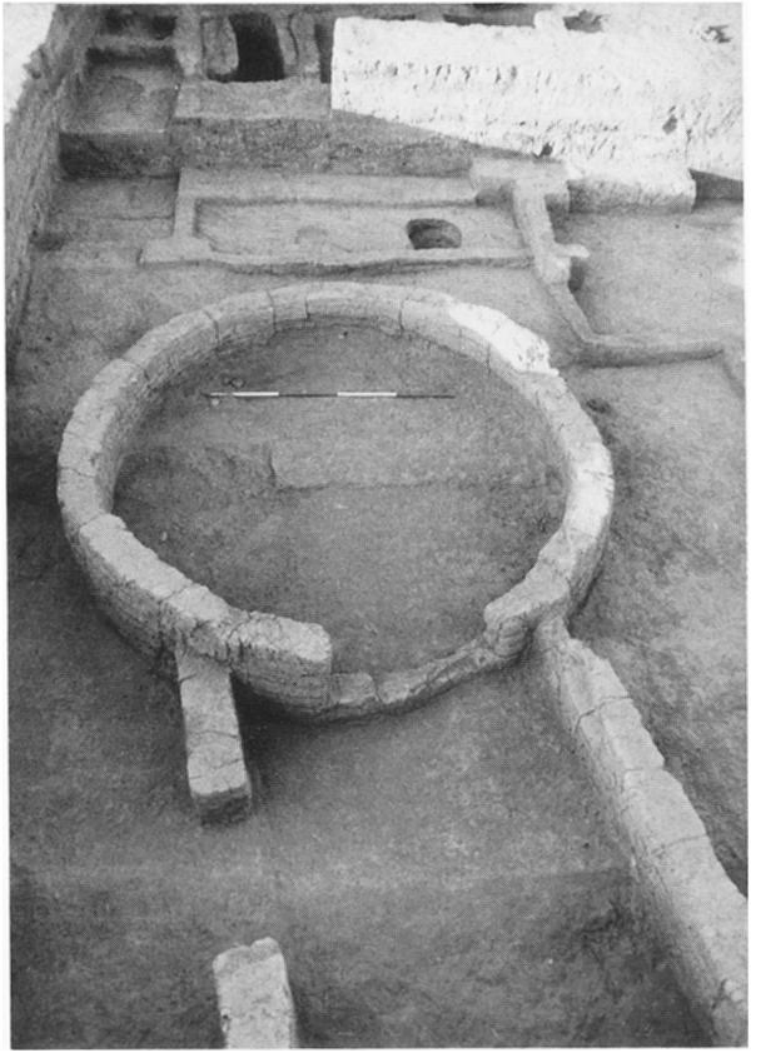

Fig. 6. Keyhole-shaped tholos in square Q15 (view from south)

length could not be established since part of the antechamber awaits excavation). The main entrance to the building seems to be an $80-\mathrm{cm}$ wide doorway in the western long wall of the antechamber, whereas the circular room was entered from this antechamber through a ca. 1-m wide doorway. The latter entrance has a mudbrick threshold (cf. fig. 6).

This tholos differs in two aspects from the ones found in the later phases of Halaf occupation at Sabi Abyad: 1) it is the only circular structure with a rectangular antechamber so far excavated at Sabi Abyad (the others are simple round buildings), and 2) it lacks the burnt interior plaster most characteristic of the later tholoi. ${ }^{17}$ Apparently, different types of tholoi were in use at Sabi Abyad but the reason for this variability is not clear. The interior diameters of the various kinds of circular buildings were the same, however, suggesting that at least the basic principles of construction were identical. Smaller tholoi are only rarely found, and larger ones are absent. Buildings with circular ground plan and rectangular antechamber are traditionally regarded as characteristic of the later stages of the Halaf period but the present evidence from Sabi Abyad clearly shows that this view is incorrect; here this kind of building appeared in one of the earliest Halaf phases of occupation known so far.

The antechamber is flanked on both sides by rectangular mudbrick buildings (fig. 3), which seem to have been added to the tholos in a slightly later stage. Flimsy traces of mudbrick walls, preserved to a height of $10-15 \mathrm{~cm}$ only, appeared northeast of the tholos. These walls do not seem to define a room but an open, unroofed area.

In the northern squares, P12 and Q12, traces of a multiroomed, rectangular house complex were unearthed, most likely to be associated with the findings in the southern trenches. Two stages of construction can be recognized in the level 4 house, both of which are closely related. The earliest one is represented by a rather large room (found in square Q12), bounded by mudbrick walls about $35 \mathrm{~cm}$ wide and

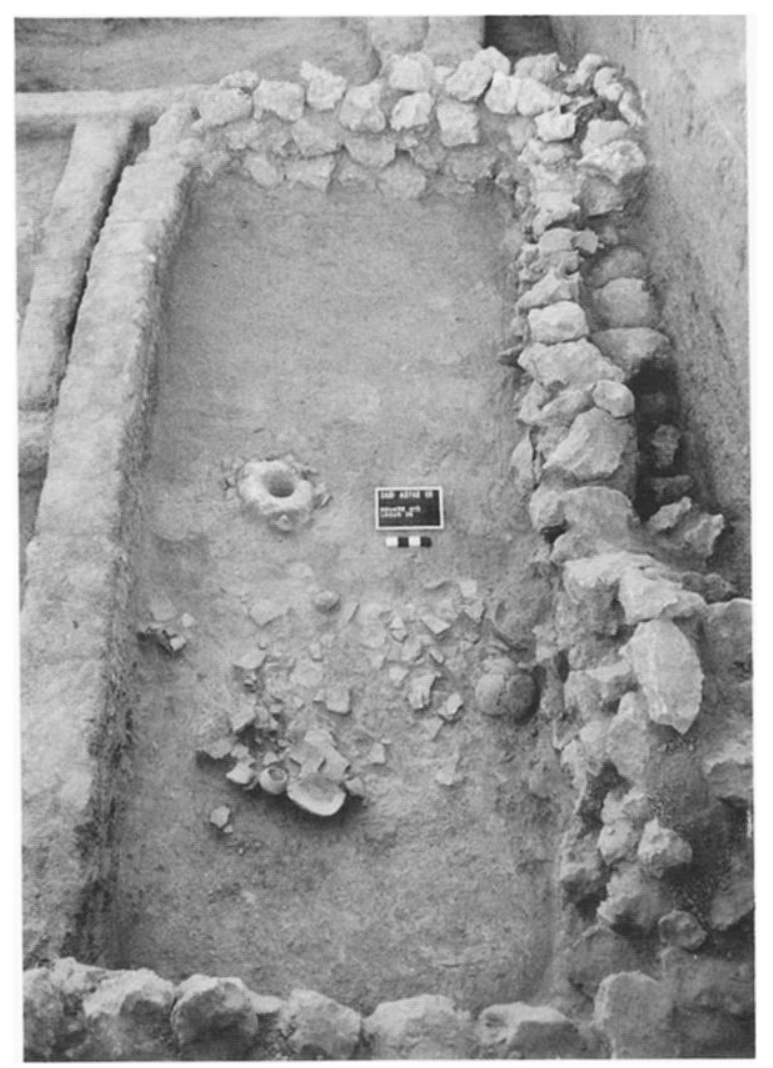

Fig. 7. Level 4 main room in square Q12 with mortar and in situ finds on floor (view from west). The stone wall actually belongs to a later phase, level 3 , but seems to be founded upon level 4 mudbrick walls.

17 Akkermans (supra n. 10) 59. 


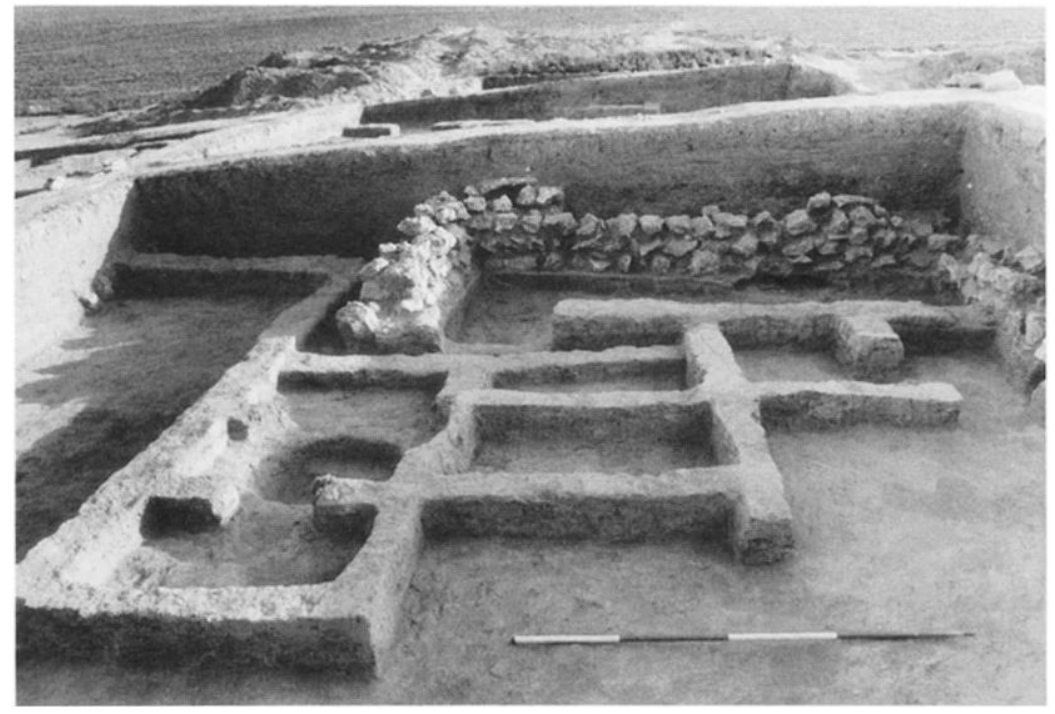

Fig. 8. Level 4 building in square Q12 (view from north). The stone wall belongs to a later phase, level 3.

simply founded on earth. A doorway ca. $1 \mathrm{~m}$ wide gave access to the room from the north. The room itself showed evidence of a hard-tamped and repeatedly renewed mud floor, into which a stone mortar had been sunk. By means of a lining of animal bones, this mortar was solidly crammed into the floor. Around this mortar, the floor was covered by broken but restorable ceramic vessels, sherd disks, bone awls and spatulas, basalt pestles, and implements of flint and obsidian, all likely to represent in-situ finds (fig. 7).

The second building stage started with the blocking of the main room's entrance with mudbricks and with the subsequent construction of a series of very small rooms, varying in size between about $1.25 \times 0.75 \mathrm{~m}$ and $1.75 \times 0.75 \mathrm{~m}$ (fig. 8). All these rooms have thin mudbrick walls $(25-30 \mathrm{~cm}$ wide), lacking any foundations. In only one instance was an exterior doorway recognized at floor level; in all other cases, access seems to have been gained either at a higher elevation or from the roof. A similar series of extremely small rooms, arranged in a row oriented east-west, was observed in the neighboring square, P12.

\section{The Pottery}

In general, the ceramics from levels 6-4 (fig. 9) closely resemble those of the earlier levels: kinds of wares, techniques of manufacture, and shapes hardly differ. Some changes do occur, however, the most important of which is the appearance of painted Fine ware. In addition, definite changes take place in the

18 A. van As and L. Jacobs, "Technological Aspects of the Prehistoric Pottery," in Akkermans ed. (supra n. 7) 215-32 finishing of the Coarse ware ceramics: both the redburnished and the decorated varieties virtually disappear.

It must be stressed that Coarse ware remains by far the major ceramic component: in levels 6 and 5 over $90 \%$ of the total sherd sample belongs to this ware, whereas in level 4 Coarse ware comprises about threequarters of the ceramic bulk. Gray-Black ware and imported Dark-faced Burnished ware is found in small but more or less constant quantities in the various levels. In level 6, painted Fine ware comprises hardly $1 \%$ of the ceramic sample. In level 5, however, the amount of Fine ware increases to over $5 \%$, whereas in level 4 it comprises around $25 \%$. In the subsequent levels, 3-1, this kind of ceramics rapidly increases to over $80 \%$ of the sample.

The appearance of Fine ware in level 6 is not a variation upon an already existing theme, but represents a true innovation in ceramic production. The pottery is made of finely textured clay and is almost exclusively lime-tempered. Most of the carefully smoothed pottery has a cream-buff or occasionally orange surface color. In all cases, the Fine ware ceramics seem to have been decorated, either painted or, less commonly, painted and incised. Decorative designs are much more complex and intricate than those found on the earlier Coarse ware painted pottery. The vast majority of the pottery was well fired at high temperatures, i.e., $800^{\circ} \mathrm{C}$ or higher, ${ }^{18}$ and has evenly colored, wholly oxidized wall sections. This may suggest the presence of advanced, two-cham-

and table V.1. 


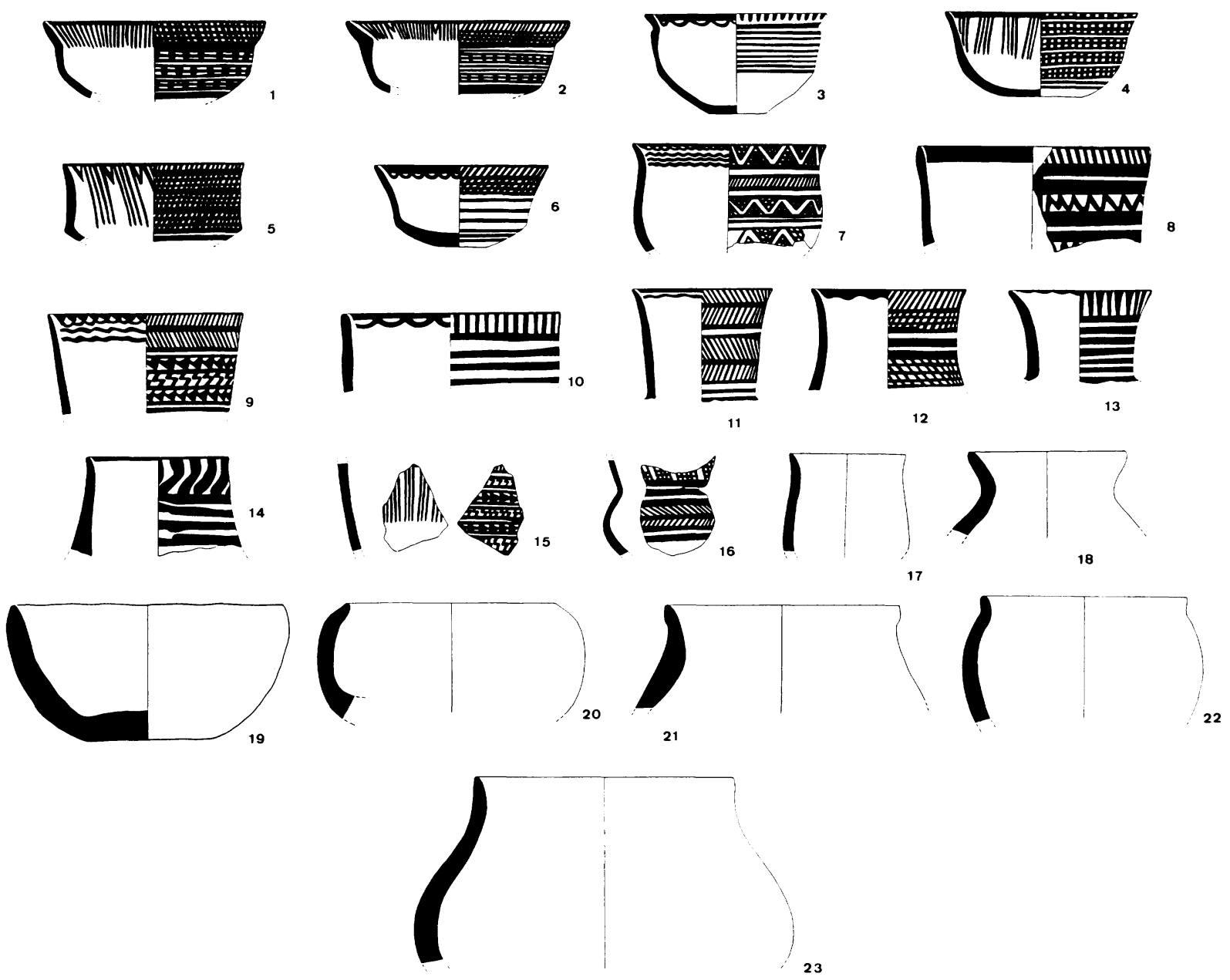

Fig. 9. Examples of Fine ware (1-17) and Coarse ware (18-23) from level 4. Fine ware is lime-tempered (except 15, which has fine sand temper), and Coarse ware has vegetal temper. 1-4, 6 (?), 7, and 16: buff with black matt paint; 5: cream with orangered matt paint; 8: buff with brown lustrous paint; 9: cream with black matt paint; 10: cream with reddish-brown matt paint; 11: greenish with brown matt paint; 12-15: buff with brown matt paint; 17: greenish fabric, undecorated; 18-23: brown fabric. Scale 1:6.

bered pottery kilns with atmospheric control (in contrast, the Coarse ware may easily have been produced in technologically much less demanding firing pits).

The decorated Fine ware from levels $6-4$ can easily be distinguished from the true Halafian pottery of the upper levels. The differences are not found so much in techniques of manufacturing as in shapes and kinds of decoration. The assemblage consists of various kinds of bowls and small jars of the angleneck type. The latter have flaring plain rims and rounded or carinated bodies and all had been carefully painted, occasionally in combination with incisions at the shoulder. ${ }^{19}$ The paint is matt, reddishbrown to black in color. The emphasis of decoration is on horizontal banding, which encloses design ele- ments in narrow zones. Usually two different motifs are used in alternating bands. In the Halafian levels 3-1 decoration is broadly executed in most cases, emphasizing the entire space rather than linear bands.

Bowls are often characterized by slightly outrolled or outturned rims not found in the Halafian ceramic inventory (Early Halaf pots have plain rims almost exclusively). Various shapes are indicated, like low, hemispherical bowls, rather large and flaring, straight-walled bowls, narrow but deep S-curved bowls and flaring, carinated bowls. More complex, carinated shapes occur as well, particularly in stratum 4 (fig. 9). In general, these bowls are simply decorated with bands of zigzags or continuous chevrons, but in level 4 designs are occasionally much more intricate;

${ }^{19}$ Akkermans (supra n. 12) fig. IV.32, no. 231. 


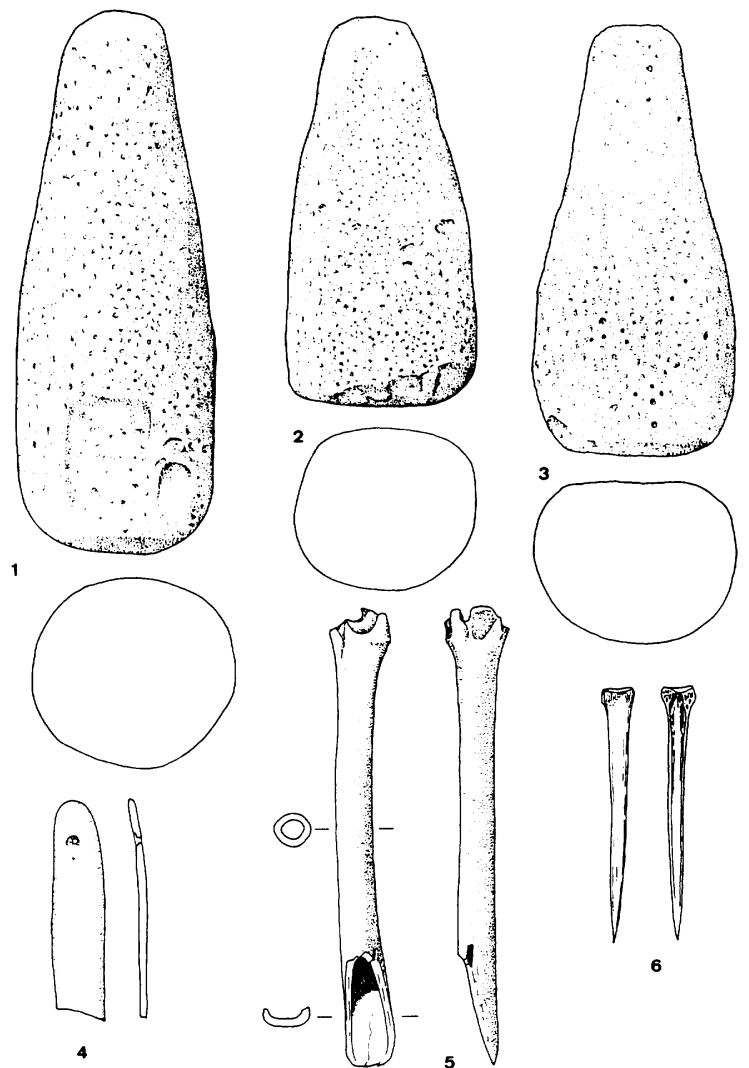

Fig. 10. Selected basalt pestles and bone objects from levels 4 (nos. 1, 2, 4), 3 (nos. 3, 6), and 2 (no. 4 ) of the southeastern mound. Scale 1:4.

these design patterns are virtually absent from the pottery from the subsequent Halaf levels 3-1.

Interestingly, many of the painted or painted-andincised ceramics closely resemble Samarran pottery from north-central Iraq in shape and decoration (cf. fig. 9: 7, 9, and 15); some kind of interaction seems to have existed between the local late sixth millennium communities of northern Syria and the Samarran settlements found further east. The first Halafian-like pottery appeared in minute quantities in level 5 and increased in importance in level 4. In terms of shape, decoration, and techniques of manufacture, these ceramics are virtually identical to those found in vast quantities in the upper three levels.

\section{Selected Small Finds}

A wide variety of stones was in use at Sabi Abyad for the production of all kinds of small objects: basalt, limestone, sandstone, granite, marble, alabaster, hematite, rock-crystal, and various as yet unidentified stones. Most commonly found (both in number and in weight) is vesicular basalt used for the production of flattened grinding slabs, mortars, and conically shaped pestles (fig. 10). Occasionally, these objects were also made of limestone, sandstone, or granite. Other kinds of stone were used in small quantities for the production of beads, pendants, axes, adzes, and some bowls. Among the finest stone objects found at Sabi Abyad are the level 4 labrets and stamp seals. So far, eight labrets have been found, four of which are made of transparent rock-crystal, the remainder of hematite. Some of these labrets have a squat appearance with a flat, slightly protruding top, whereas others are of a taller shape with a pointed, conical head. Most likely, these carefully finished items served as ear or lip ornaments. ${ }^{20}$

In addition, two hematite stamp seals were recovered from the level 4 fill (fig. 11: 2-3). One takes the shape of a rounded button seal with a perforated ridge handle smoothly rising out of the top and has a design of 10 shallow, rounded drillings encircled by incised hatchmarks around the border of the seal. The other is a conical-shaped seal, centrally perforated from the top with three shallow, rounded drillings surrounded by double engraved lines.

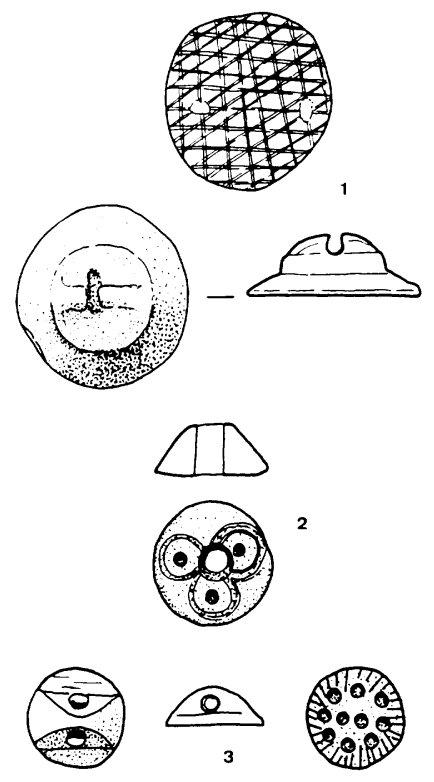

Fig. 11. Stone stamp seals. 1) Stamp seal with perforated ridge handle, gray-green chlorite (?), northeastern mound pre-Halaf Neolithic; 2) stamp seal, conically-shaped with central perforation, hematite, level 4; and 3) stamp seal with perforated ridge handle, hematite, level 4. Scale 1:2.

${ }^{20}$ F. Hole et al., Prehistory and Human Ecology of the Deh Luran Plain (Ann Arbor 1969) 235-36. 


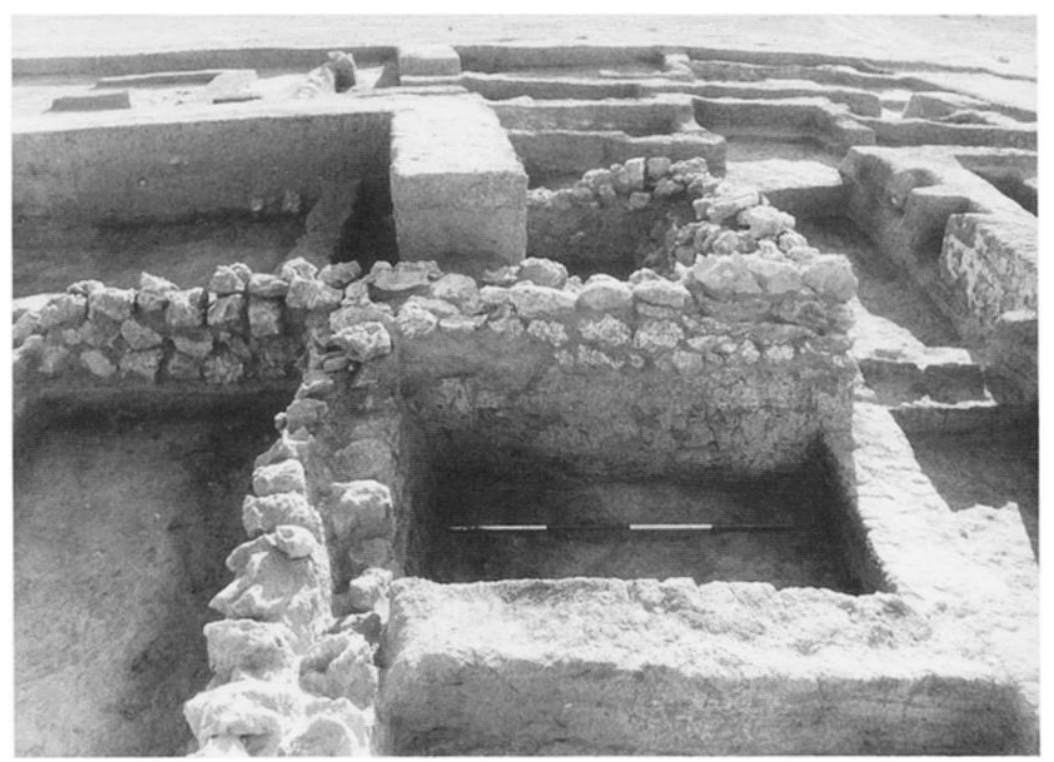

Fig. 12. Level 3 stone wall with tower-like projection (view from the west). On the lower part of the wall the carefully applied plaster is still visible.

\section{THE EARLY HALAF PERIOD: LEVELS 3-1}

\section{Stratigraphy and Architecture}

The level 3 remains, partially standing to a height of $1.5 \mathrm{~m}$, were among the best preserved at Sabi Abyad and could be traced over an extensive area, i.e., around $800 \mathrm{~m}^{2}$. Level 3 seems to have started with the partial leveling of the lower level 4 architectural features in the north-central squares (the areas along the southern slope seem to have already been given up for occupation at an earlier stage) and the construction of a huge stone wall. This wall consisted of hewn gypsum blocks, at least two rows wide (about $0.8 \mathrm{~m}$ ), which must have come from the Pleistocene terraces at a distance of 5-10 km east of Sabi Abyad. The wall is oriented more or less east-west and could be traced over a considerable distance in squares P12, $\mathrm{Q} 12$, and Q13; the presence of stones below the floor level of building III in the neighboring square, R12, strongly suggests a continuation of the wall to the east. In square P12, the wall seems to veer slightly toward the south but the most curious feature is the heavily enforced and almost tower-like projection in square Q13 (fig. 12). For the most part, the wall is well preserved (only in square P12 was it disturbed by pits coming down from Late Bronze Age phases of occupation) and it still stands to its original height of about $1.5 \mathrm{~m}$. That it was not sunk into the tell is shown by an exterior plaster facade and the presence of the large mudbrick building built against this facade soon after the construction of the wall. The southern, ex- terior facade was carefully finished: the stones were hewn regularly to create a smooth, more or less straight surface and subsequently a ca. 2-cm thick layer of mud plaster was applied, in its turn covered by a thin (ca. $2-3 \mathrm{~mm}$ ) white coating. In contrast, the interior was roughly executed, with the wall becoming increasingly narrow toward the top, and completely filled with loose and rather clean soil. Most likely, this wall first served as a retaining wall supporting a terrace on top and along the northern slope of the southeastern mound. The parts oriented north-south may have served as "grips," clamping the support wall into the terrace and strengthening it to withstand the terrace's lateral thrust. If a terrace was indeed present in the northern squares, it must have been one of exceptional size. So far its northern boundaries have not yet been found and, when taking into account that already in level 4 times the southeastern mound sloped considerably toward the north, it follows that enormous amounts of earth must have been brought in to create this terrace. The function of the terrace still remains enigmatic. In the areas enclosed by the wall no architecture or other features were encountered and originally the wall does not seem to have carried a mudbrick superstructure. Only at a later stage were parts of the stone wall incorporated in the large mudbrick structure, building I (see below), found in square Q13 (fig. 13).

At a certain time, the terrace and its stone wall seem to have lost their original meaning. Extensive mudbrick complexes were erected in the areas immedi- 


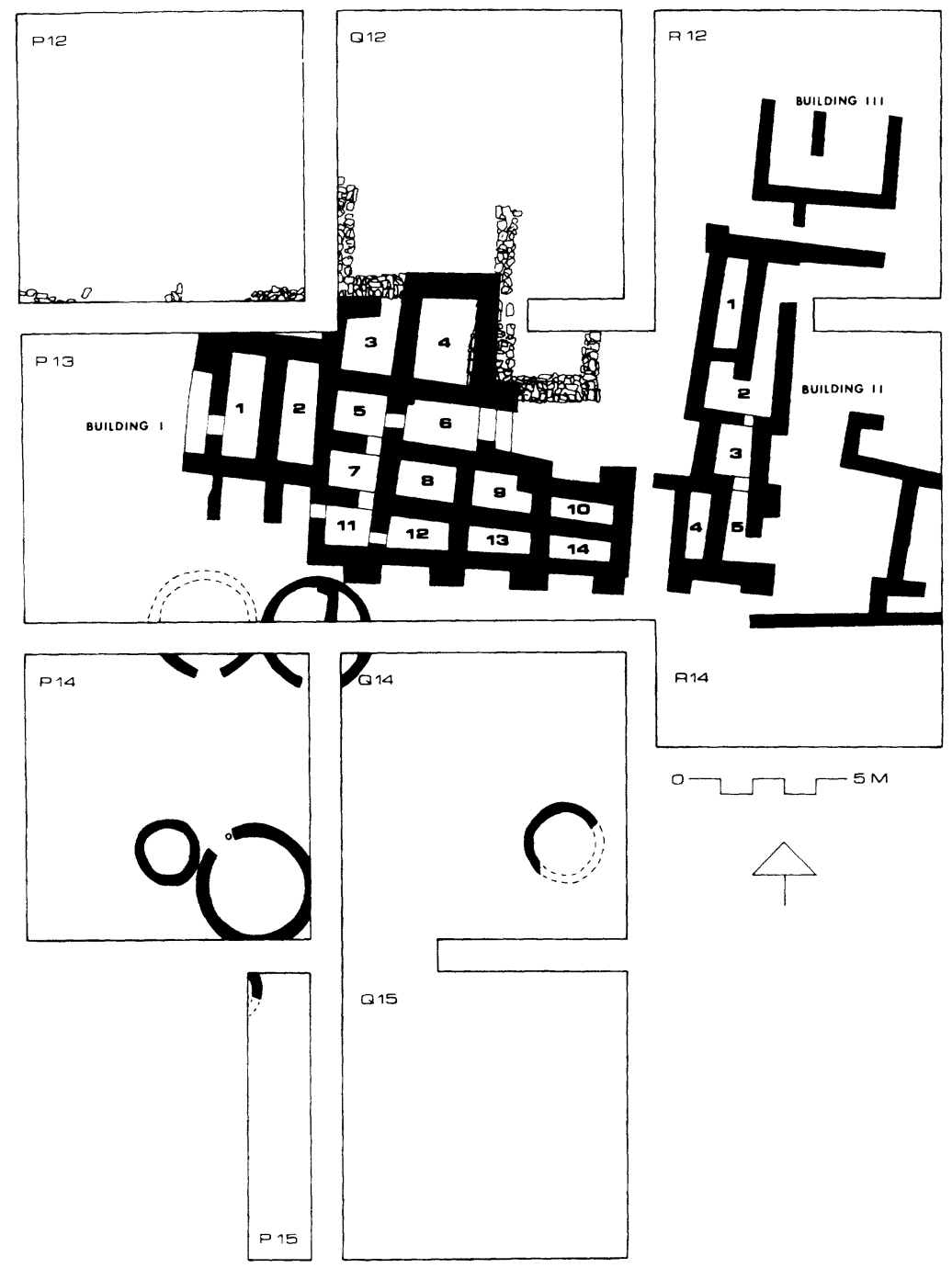

Fig. 13. Plan of level 3 architecture on the southeastern mound (early phase)

ately south of the retaining wall (thus hiding it largely from view) and parts of the wall were used as a foundation for mudbrick walls. The wall itself, however, was left wholly intact. Moreover, no structures were found in the area actually enclosed by the terrace wall; for some reason this area was left untouched.

On top of the southeastern mound we now find a large rectilinear complex, basically consisting of two separate but closely related buildings, surrounded on the slopes by various circular and rectangular auxiliary structures (fig. 13). Parts of this well-preserved architecture (with walls standing to a height of 0.5 to $1.2 \mathrm{~m}$ ) had already been exposed in $1986,{ }^{21}$ and during the 1988 season we uncovered the remaining portions and determined its plan. The western building, here termed building I, comprises 14 small to very small rooms (the largest one hardly covering $5 \mathrm{~m}^{2}$ ). The building was constructed of thick mudbrick walls (width ca. 50-60 cm), consisting of longitudinal rows of mudbricks supplemented by bricks half the usual size. The walls of the two westernmost rooms, 1 and 2 (i.e., those excavated in 1986), were founded on stones but whether or not this holds for the other walls as well remains to be investigated (so far, only one of the newly excavated walls has been partially removed; this one indeed had a foundation of stones, although much smaller than those of the westernmost walls). We have some indications that rooms 1 and 2 were added to the main building (rooms 3-14) at a slightly later stage: 1) the northsouth orientation of the rooms, in marked contrast with the other units all oriented east-west, 2) the

${ }^{21}$ Akkermans 1987, Paléorient (supra n. 7) 27. Akkermans (supra n. 10) 36. 


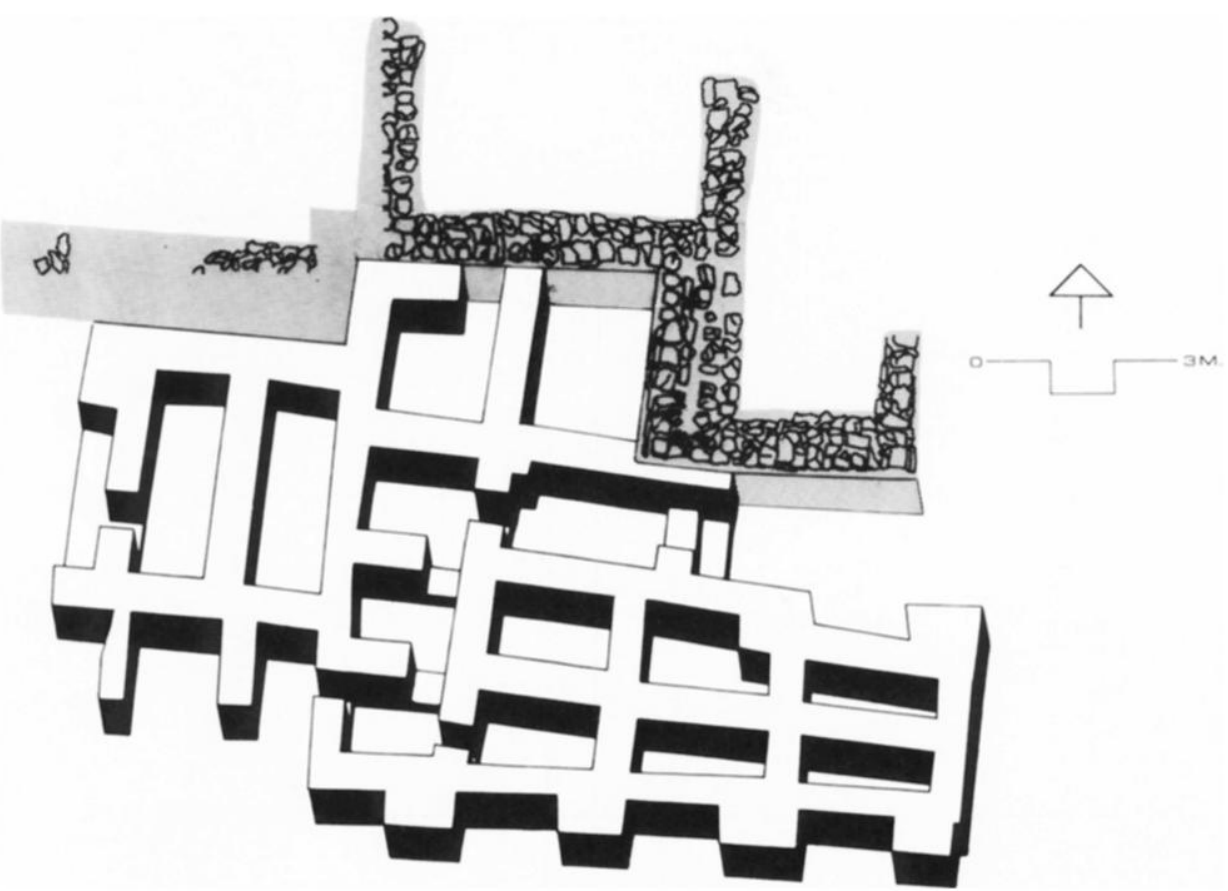

Fig. 14. Isometric reconstruction of level 3 building I (built against stone wall)

shifted east-west walls, extending northward with regard to the building's main axis, and 3) the separate, stepped entrance from the west. Moreover, in one of the western rooms a tannur-like oven was present, not found in any of the other rooms. The building's exterior facade was supported by a series of large buttresses at wall junctions. In the north, the mudbrick walls were partly set against the plastered stone wall and partly built upon this stone wall (fig. 14).

Circulation through the building was enhanced by a series of narrow doorways (width ca. $40-50 \mathrm{~cm}$ ), each having a mudbrick threshold. Some rooms lacked an entrance at floor level, however, and apparently these rooms were accessible either through a passage situated at a higher elevation in the wall or from the roof of the building. In one instance, a doorway appeared to have been blocked by mudbricks (i.e., the doorway between rooms 11 and 12). The main entrance to the building, about $1 \mathrm{~m}$ wide, was found in the northeast, situated at the end of a $1.80-\mathrm{m}$ wide passage between the stone wall and one of the newly erected mudbrick walls (figs. 14-15). This en-

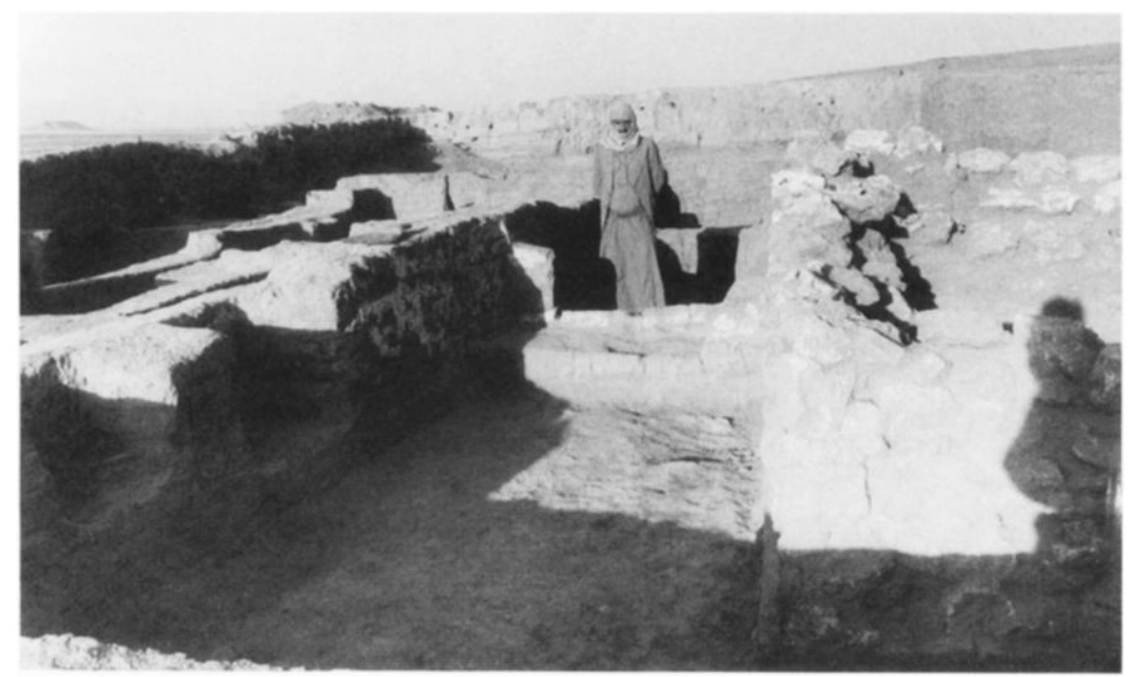

Fig. 15. Main entrance with two steps of level 3 building I (view from east) 


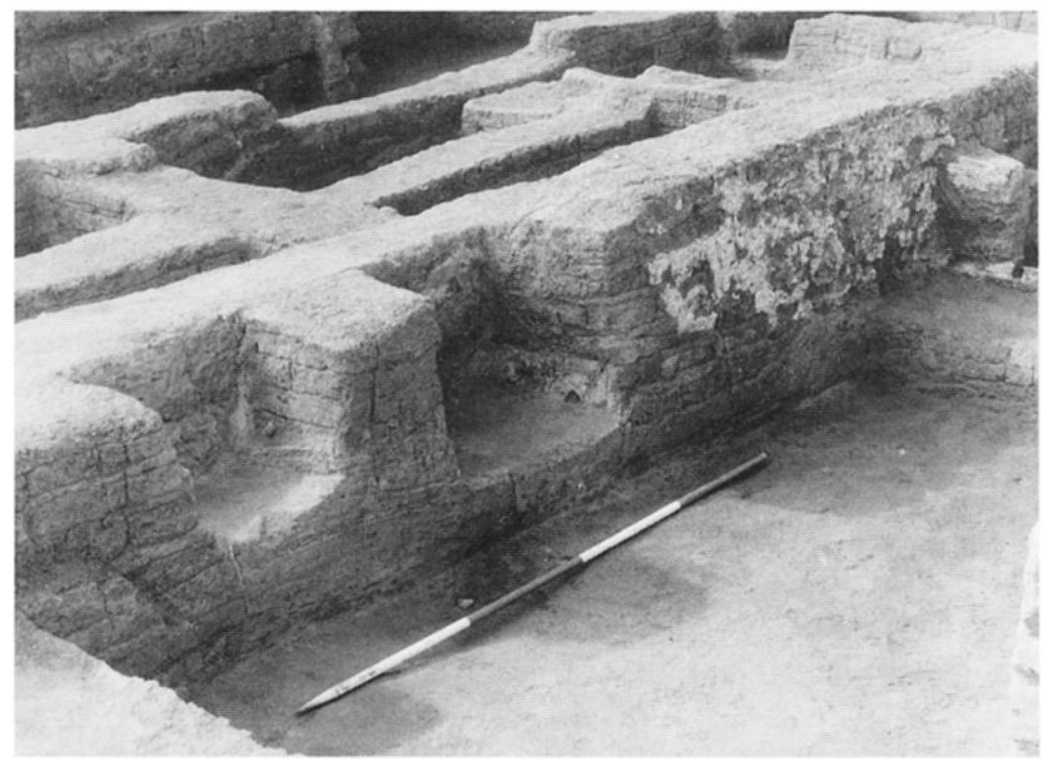

Fig. 16. White-plastered mudbrick wall with two niches. Level 3 building I (view from northeast).

trance had a somewhat monumental appearance with its low, thickly white-plastered staircase with two steps. The stone wall next to this entrance still contains its white coating upon a mud plaster, whereas the opposite mudbrick wall has a thick and at least twicerenewed calcite plaster identical to that of the staircase. ${ }^{22}$ In addition, this mudbrick wall showed evidence of a large niche, divided at a later stage into two smaller, plastered niches with a shallow basin in front (fig. 16). Finally, a third entrance is found in the southwest (room 11), but it can be questioned whether this one was meant to form a link between the exterior and the interior. The presence of two heavily eroded walls in front of this doorway suggests that originally two further rooms were added to the building and that the entrance served as an interior connection. In size, location, and finishing (mudbrick threshold, simple mud plaster), too, the entrance closely resembles the other interior doorways linking the various rooms.

It may be the case that the building was also accessible from the north, i.e., from the terrace situated higher up. The major indication pointing in this direction comes from room 3 . The walls bounding this room were preserved to a considerable height (ca. $1 \mathrm{~m}$ ) and did not show any signs of a doorway, except perhaps in the north. Here it appeared that the mudbrick walls, set against the stone wall, did not join: a

\footnotetext{
22 X-ray diffraction made it clear that exterior wall plastering at Sabi Abyad involved the use of calcite. Pure gypsum or gypsum in association with calcite was used in the plaster-
}

ca. $60-\mathrm{cm}$ wide opening is present, in perfect agreement in size and location with the doorways found in the rooms further south. Moreover, the mudbrick wall founded upon the stone wall ends precisely at the junction with the mudbrick wall running northsouth; at this point the stone wall also contains a doorpivot stone. In view of the considerable height differences between the floor level in room 3 and the neighboring terrace, it seems that some kind of ladder must have been used to enter the room. In this sense, room 3 must have had an almost cellar-like appearance.

We have indications that the building consisted of two stories: 1) the extremely small size of all the rooms, which are hardly suitable for living in; 2) the lack of doorways in various rooms, suggesting that these were accessible from the roof only; 3) the considerable width of the walls, which are all much stronger than necessary for simple, one-story constructions (it must be recalled that all auxiliary buildings had thin walls only one brick wide); 4) the investment in stone foundations; 5 ) the presence of large buttresses along the exterior facade; and 6) the virtual lack of domestic features like ovens, benches, and bins in these rooms. Other finds were rare, too, as most rooms were wholly devoid of finds except for materials undoubtedly representing secondary deposits. The floor of the westernmost room yielded a number of small ceramic vessels, a flattened pierced

ing of pits and shallow basins. See L. Rehhoff et al., "Plasters: Gypsum or Calcite? A Preliminary Case Study of Syrian Plasters," Paléorient (in press). 

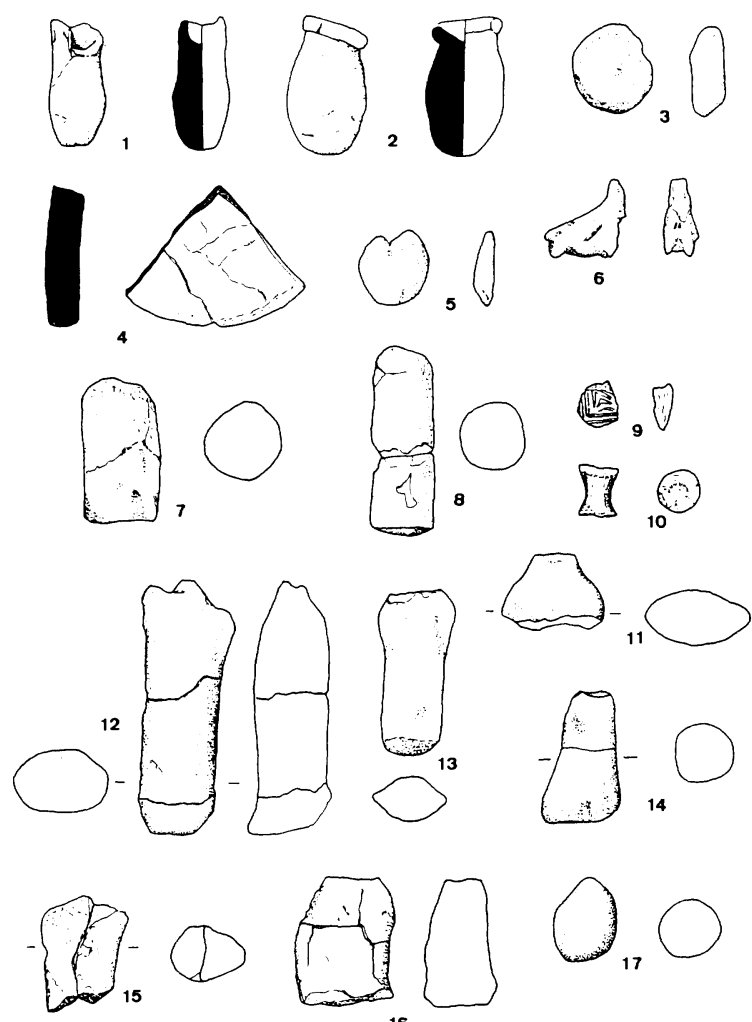

Fig. 17. Selection of unbaked clay objects found on the floor of level 3 building I, room 11. Scale 1:4.

stone, and a worked bone fragment, all considered to be in situ. ${ }^{23}$ Another in-situ find appeared in room 11: here a pile of unbaked clay objects of all sorts were found on the floor, including some very stylized human and animal figurines, miniature vessels, balls, rectangular plaquettes, disks, and cones (fig. 17). One fragment shows traces of a stamp seal impression (fig. 17: 9). Finally, in room 5 fragments of large storage vessels appeared, whereas in the neighboring room 4 a complete but warped, painted bowl was found on the floor.

Building II, oriented more or less north-south (fig. 18), is of a rather curious shape, elongated and extremely narrow. The building is about $11 \mathrm{~m}$ long and $3 \mathrm{~m}$ wide, and is divided into a parallel series of tiny rooms and narrow passages. Hardly any finds came from this building, apart from a complete, painted bowl found on the floor of room 4. Except for its overall shape, the eastern building resembles the western one in all respects: the size and shape of the tiny rooms, the width and the construction of the small doorways, the size of the walls, and the presence of buttresses along the exterior facade are all similar. The central niche in the eastern wall has a low, whiteplastered bench of mudbricks founded on stones. That both buildings were designed and constructed at more or less the same time is also suggested by the course of the southern facade, which wholly adheres to that of the western building. Interestingly enough, hardly any leveling of the tell surface seems to have taken place to facilitate the construction of building II: its walls simply follow the course of the slope and, as a consequence, wall bases differ considerably in elevation. A good example is the eastern wall of the building, which shows differences in wall base elevation of up to $50 \mathrm{~cm}$ over a distance of only $10 \mathrm{~m}$.

Building II was accessible from the east only, through two doorways situated at the far ends of the building. At least in front of the southeastern entrance a court was present, bordered by white-plastered

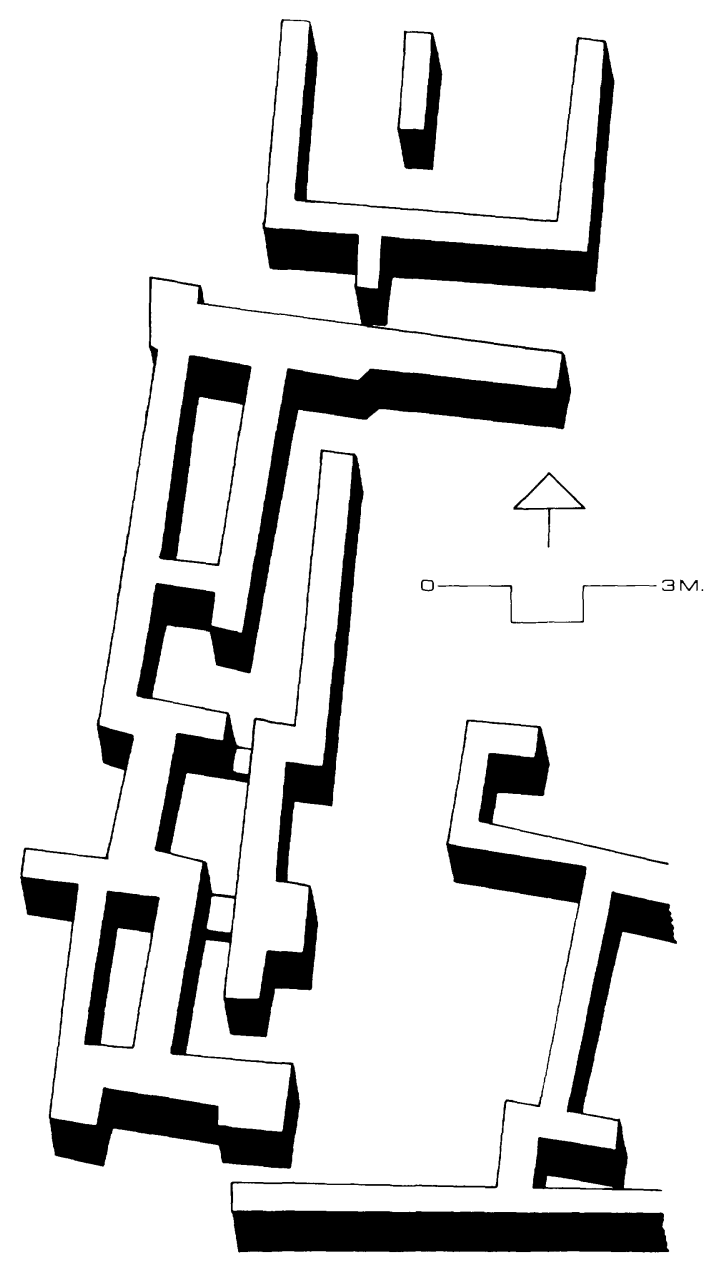

Fig. 18. Isometric reconstruction of level 3 building II

23 Akkermans (supra n. 10) 39. 


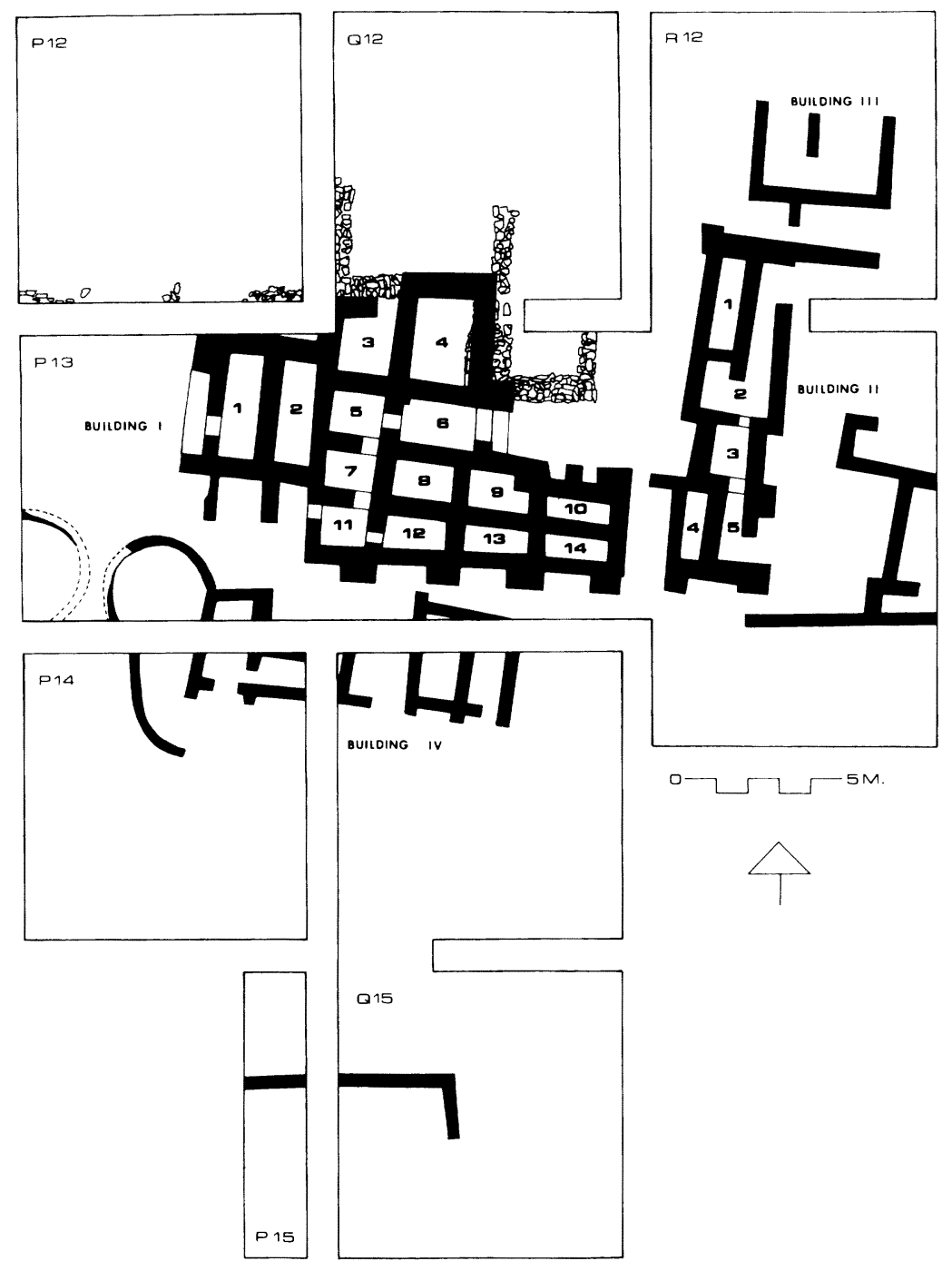

Fig. 19. Plan of level 3 architecture on the southeastern mound (late phase)

walls. Along the court wall opposite the entrance over 1,000 sling missiles of unbaked clay were found, all stored in narrow, rounded containers sunk into the floor. The exterior facades of the building were largely covered by a white coating.

On the slopes the main architecture was surrounded by a series of circular and rectangular subsidiary structures. A distinct temporal difference in the construction of these features can be noted. Whereas the main building gave evidence of minor alterations only and remained in use for a considerable period of time, its surroundings witnessed a lively domestic activity with structures being rapidly replaced. During the 1986 season a series of tholoi were

\footnotetext{
24 Akkermans 1987, Paléorient (supra n. 7) 26.

25 Akkermans (supra n. 10) 59.

26 Akkermans (supra n. 10) 29, 64. W. van Zeist and W.
}

found in square P14, at that time considered to represent a separate building level. ${ }^{24}$ It now seems clear, however, that these tholoi represent the earliest series of auxiliary structures to be associated with the main rectilinear level 3 buildings (fig. 13). Over the course of time, these tholoi were supplanted by other circular structures, in their turn finally replaced by small, multiroomed rectangular buildings.

The Sabi Abyad tholoi have already been discussed in detail elsewhere. ${ }^{25}$ Most likely these structures represent storage facilities. Both in 1986 and 1988 vast quantities of burnt wheat, virtually free of field weeds and undoubtedly representing a burnt stockpile, ${ }^{26}$ were found around some of the tholoi. Several cubic

Waterbolk-Van Rooijen, "Plant Remains from Tell Sabi Abyad," in Akkermans ed. (supra n. 7) 332. 

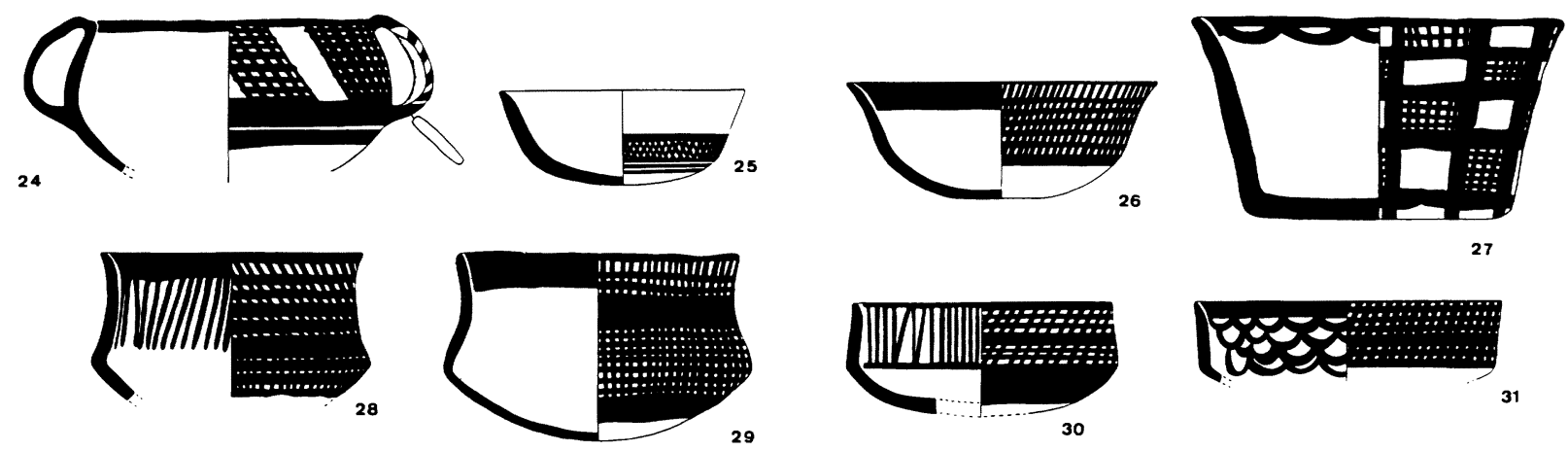

30
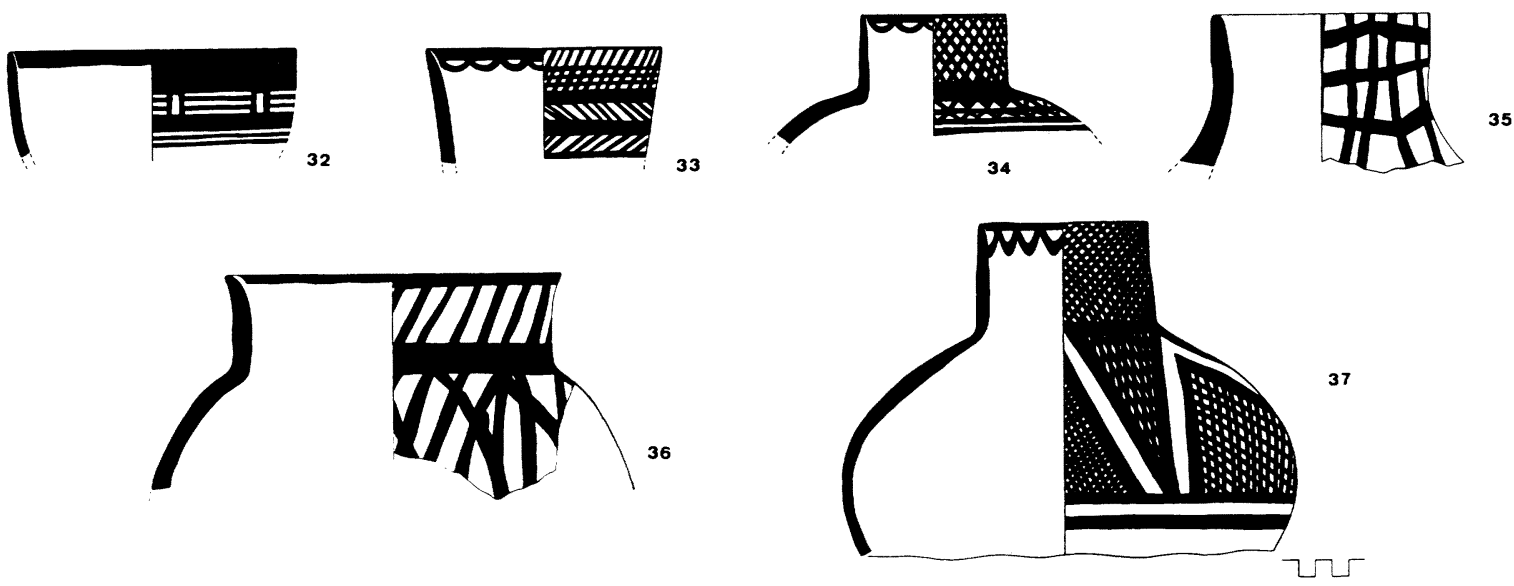

Fig. 20. Examples of Fine lime-tempered ware (24, 26-37) and Coarse ware (25) from level 3. 24, 34: cream with black matt paint (34 with slight core coloration); 25: buff with black matt paint, vegetal-and-sand temper; 26-27, 29: buff with black matt paint; 30, 32, 35: buff with brown matt paint; 31: buff with black lustrous (?) paint; 33: buff with brown lustrous (?) paint; 36: cream with brown matt paint; 37: buff with reddish-brown lustrous paint. Scale 1:6.

meters of burnt cereals appeared in a $5-30 \mathrm{~cm}$ thick layer, spread out over square P14, almost half of Q14, and part of Q13.

Ultimately, the various level 3 tholoi in the southern area seem to have been replaced by a rectangular structure (building IV) immediately south of the main buildings (fig. 19). This building consists of a series of elongated, narrow rooms with thin mudbrick walls lacking any foundations. Access to the tiny rooms was gained from the south through narrow doorways, marked on both sides by buttresses. In the open area immediately in front of the easternmost rooms, traces were found of a largely eroded pavement of small sherds and whitish fragments of limestone or gypsum.

Finally, in the northern square R12 we find a small two-roomed structure termed building III. Basically, this building consists of one room, measuring ca. $3.00 \times 2.70 \mathrm{~m}$ and divided by a small, freestanding wall into two smaller units (fig. 19). The northern face of the building was wholly open, thus giving this structure a stable-like appearance.

Somewhere around 5050 B.C., the level 3 occupation seems to have come to an end. The buildings went out of use and fallen mudbricks (no doubt the remains of the structures' collapsed upper walls) and occupational debris filled the lower part of the rooms: level 2. Small pits dug into the fill of these rooms indicate that, after their abandonment, the former buildings still stood to some height and were reused for various open-air domestic activities. Numerous pits appeared as well as tannur-like ovens, fireplaces, and small white-plastered basins, around which thick layers of ashes and other occupational debris had rapidly accumulated. No true dwellings have yet been uncovered; apparently, the residential architecture contracted or was moved to another part of the site.

The topmost level, level 1, consists of multiroomed, rectilinear architecture, covering the top of the southeastern mound in a ribbon-like manner. Basically, there seem to have been three separate buildings, divided from each other by narrow alleys oriented more or less north-south. The westernmost structure, building $\mathrm{I}$, is only preserved in part; this building was largely destroyed by a large Late Bronze Age pit coming down from the tell's surface in this area. Building II, in the center, mainly consists of a series 

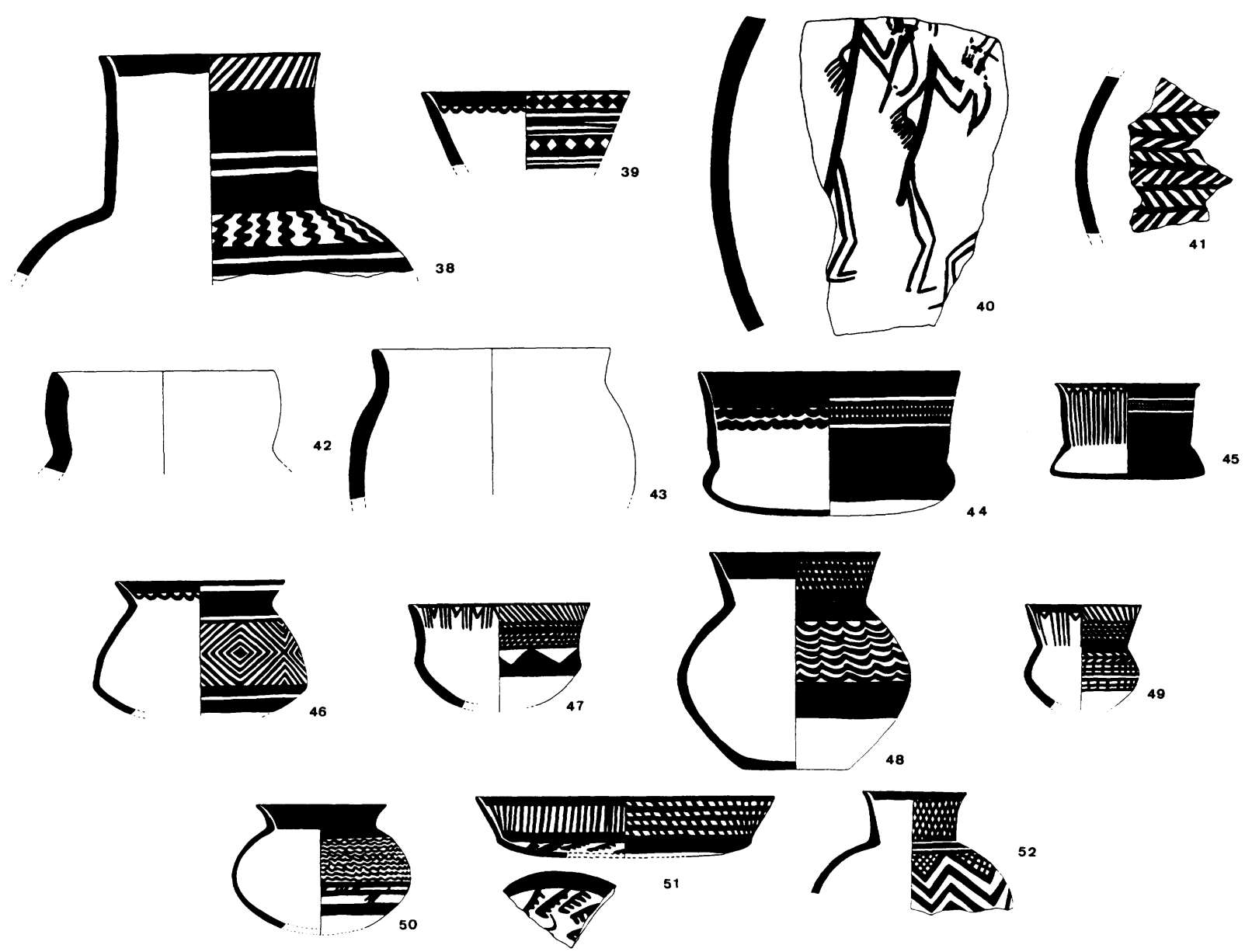

Fig. 21. Examples of Fine lime-tempered ware (38-41) and Coarse vegetal-tempered ware (42-43) from level 3, and Fine limetempered ware (44-52) from levels 2-1. Level 3: 38: buff with black matt paint; 39: buff with black lustrous paint; 40-41: buff with brown matt paint; 42-43: brown fabric, dark core (42 with scraped surface). Levels 2-1: 44-45, 47 (?), 49-50: buff with lustrous black paint; 46 : cream with black matt paint; 48 : buff with brown matt paint; 51 : buff with black matt paint; and 52: cream with black lustrous paint. Scale 1:6.

of narrow but elongated rooms, oriented either north-south or east-west. The wall faces are coated with mud plaster, in some rooms covered by a thick white coating. A radiocarbon sample from burnt grain found on the floor of the easternmost room of building II yielded a date of $5025 \pm 30$ B.C. (table 1). In front of the central building a tholos was present, partly sunk into the tell slope. The easternmost building, III, consists of a rectangular main room, measuring ca. $3.00 \times 2.25 \mathrm{~m}$, supplemented by two much smaller (and partially preserved) rooms in the east. In the main room a small oven appeared, partly sunk into the floor and with a domed superstructure. An opening was present at floor level. On the floor immediately west of the oven two small pestles (one of basalt, the other of granite), a stone hammer, and a broken but restorable, painted jar were found.

\section{The Pottery}

The ceramics from the topmost levels (figs. 20-21) can be described as Early Halaf with certainty. ${ }^{27}$ Early Halaf pottery is said to have been uncovered in stratified contexts at other sites (e.g., Tell Halaf, Tell Aqab, Arpachiyah) but, despite some obvious parallels, the Sabi Abyad pottery assemblage as a whole strongly deviates from those found elsewhere. To some extent this may be due to regional variability in pottery production but more often it seems that chronological variables.are at work: the Halaf phases of occupation at Sabi Abyad are definitely earlier than those termed Early Halaf at other sites.

Fine ware is now by far dominant. As before, these ceramics have all been made of finely textured clay and are virtually all lime-tempered. The generally buff-colored pottery was fired up to $950^{\circ} \mathrm{C}$ and com-

27 For a detailed account, see Akkermans (supra n. 12). 
plex kilns, like those found at Yarim Tepe II, must have been in use. ${ }^{28}$ That this pottery was locally made at Sabi Abyad is suggested by the repeated occurrence of crumbly and deformed, overfired vessels and true wasters. The vast majority of the pottery is busily painted; undecorated Fine ware appears in very small numbers and occasionally shows an overall burnish.

As for the shapes, it seems that jars were most common, closely followed by bowls of various kinds. Vessels with an S-shaped profile or of the hole-mouth type (always with an inwardly beveled rim) are rare, accounting for only $2-3 \%$ of the assemblage. Jars are flaring or occasionally straight, angle-necked vessels. Most of these jars are rather low and small, but large storage vessels (with rim diameters up to $36 \mathrm{~cm}$ ) also occur. The body is globular in most cases although a sharp carination is not uncommon. Bases are always rounded or slightly sagging; flat jar bases seem to be a characteristic late Halaf feature. ${ }^{29}$

Bowls show the largest variability in shape, almost all of them busily painted. Among the most characteristic shapes found in levels 3-1 (although in rather limited numbers) are the so-called "Arpachiyah cream bowls," long considered to be one of the most typical Halafian vessel forms (fig. 21: 44-45). Some of the Sabi Abyad examples were extremely well made with very thin, almost eggshell-like walls and delicate decoration, resembling some of the finest cream bowls from Arpachiyah in northern Iraq. ${ }^{30}$ The most common type of bowls are the rather large, straight-sided vessels, accounting for almost half of all the bowl fragments (fig. 20: 27). Apart from their size and shape, these bowls differ in another major respect from the other bowls at Sabi Abyad, i.e., the kind of decoration. Whereas the other bowl groups show a wide variety of designs wholly interchangeable within the categories, the range of designs used for the straight-sided vessels is highly restricted (mainly crosshatched diamonds arranged in one or more continuous bands or vertical panels) and virtually limited in distribution to these bowls only. A rare kind of vessel is the low hemispherical bowl with wide loop handles (fig. 20: 24).

\footnotetext{
${ }^{28}$ See van As and Jacobs (supra n. 18) table V.1. R. Munchaev and N. Merpert, "The Archaeological Research in the Sinjar Valley (1971)," Sumer 27 (1971) 30. M. Molist, Les structures de combustion au Proche-Orient néolithique (10.000-3700 B.C.) (Lyons 1986).

${ }^{29}$ Flat bases were very common at mid-fifth millennium Khirbet esh-Shenef, about $3 \mathrm{~km}$ south of Sabi Abyad; cf. P.M.M.G. Akkermans and M. Teeuwisse, "Soundings at Khirbet esh-Shenef, a Later Halaf Settlement in the Balikh Valley, Northern Syria," AAS (in press).

30 Mallowan and Rose (supra n. 1) 132 and fig. 63.1.
}

Coarse ware appears in small numbers in levels 31 and, in contrast to the earlier levels, is in most cases mineral-tempered. Shapes are simple and mainly indicate plain-rim bowls, hole-mouth pots, and jar-like vessels with low, straight collars. ${ }^{31}$ So-called husking trays are still present and, as in the lower levels, these wide, low, coarsely made vessels have either shallow ridges or finger-impressed pits on the interior. Husking trays can be considered an integral part of the Early Halaf ceramic inventory. ${ }^{32}$

Finally, Gray-Black ware and imported Dark-faced Burnished ware are still found in small quantities. This light-gray to dark-black and in most cases burnished pottery mainly consists of flaring, carinated bowls, hole-mouth pots, and angle-necked jars. In addition, a few fragments of plain-rim bowls, S-shaped pots, and jars with low, straight necks are present. Levels 3-1 seem to have been the last Halaf phases to contain Dark-faced Burnished ware from the Mediterranean coastal region; no such pottery appeared at the early to mid-fifth millennium Balikh sites of Damishliyya and Khirbet esh-Shenef. ${ }^{33}$

\section{EXCAVATIONS ON THE TOP OF SABI ABYAD AND ON THE NORTHEASTERN MOUND}

Late sixth-millennium remains have also been reached in narrow soundings in the northeastern part of Sabi Abyad, which is characterized by a flat bulge rising about $5 \mathrm{~m}$ above the surrounding fields (fig. 2). The northern slope is relatively steep but the mound slopes gently in an easterly and particularly southerly direction. The 1986 excavations yielded scanty traces of Halafian settlement, only in the topmost strata along the northern slope. ${ }^{34}$ The majority of the trenches seemed to contain a thick accumulation of Halafian debris layers, resting on a similar pre-Halaf Neolithic debris accumulation. Trenches laid out in 1988 and oriented east-west, however, yielded traces of substantial rectilinear and circular Halaf architecture still standing to a height of up to $1 \mathrm{~m}$. When taking the present evidence into account, there can be little doubt that Halaf occupation concentrated along the upper eastern slope of the northeastern

${ }^{31}$ Akkermans (supra n. 12) figs. IV.11-19.

${ }^{32}$ Earlier, I suggested incorrectly that these husking trays should perhaps be viewed as intrusive in the Halaf phases at Sabi Abyad, i.e., that they originally belonged to an earlier level of occupation at the site; cf. Akkermans (supra n. 12) 115.

${ }^{33}$ Cf. P.M.M.G. Akkermans, "The Soundings at Tell Damishliyya," in M.N. van Loon ed., Hammam et-Turkman I (Istanbul 1988) 19-67; Akkermans and Teeuwisse (supra n. 29).

${ }^{34}$ Cf. Akkermans (supra n. 10) 19-22. 

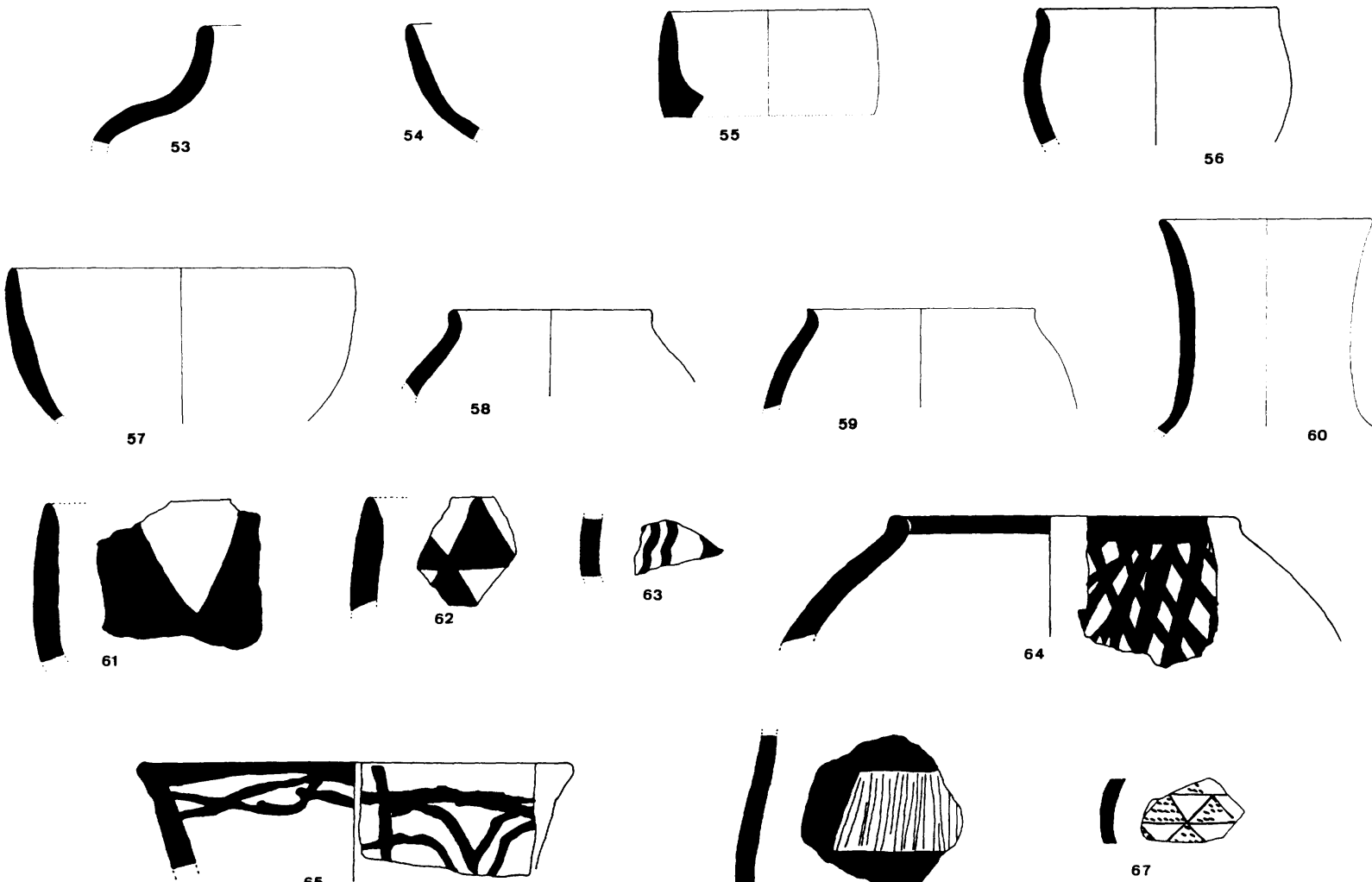

Fig. 22. Examples of pre-Halafian Neolithic ceramics from the northeastern mound. Coarse ware $(\mathbf{5 3}-\mathbf{5 7}, \mathbf{6 1}-\mathbf{6 5})$ has vegetal temper; all other wares have grit temper. 53: pink fabric; 54: buff, burnished, red-slipped; 55, 57: buff fabric; 56: buff with red-slipped surface; 58: buff, burnished, brown-slipped Fine ware; 59: buff, burnished Fine ware; 60: brown, burnished Darkfaced Burnished ware; 61-62: buff, burnished, red paint; 63: buff with brown paint; 64: pink, burnished, red paint; 65: buff with black paint; 66: brown, burnished, red paint, with very thin incision, Dark-faced Burnished ware; and 67: Gray, burnished, incised Gray-Black ware. Scale 1:6.

mound. The extent of Halaf occupation in this area must have been rather limited, however, and perhaps consisted of only one isolated structure for living. The duration of settlement must have been limited as well, for only one main level of Halaf occupation has been recognized so far.

In 1988, pre-Halaf Neolithic strata were reached on a limited scale only in the topmost trench, U5, and in the narrow trench $\mathrm{Y} 5$ at the foot of the eastern slope. In trench U5 pre-Halaf deposits have so far been dug to a depth of $2.5 \mathrm{~m}$, i.e., to an estimated half of the pre-Halaf Neolithic sequence on the northeastern mound. Apart from a number of fireplaces, virtually no architectural features have been encountered, suggesting that the area was largely used for open-air domestic activities. In trench Y5 two wall fragments and an associated floor level were encountered, following a 1.5-m thick deposit of red-brown clay intermingled with lenses of ash and charcoal. Virgin soil has not yet been reached, despite the fact that this lowest trench reached a depth of almost $2 \mathrm{~m}$ below the level of the surrounding fields. Interest- ingly, the artifact assemblages (ceramics, lithics, etc.) from the topmost trench (U5) hardly differ from those of the lower trench (Y5). It is suggested that either the original Neolithic mound was small and very steep and that occupation followed the course of the slope, or that a considerable part of the mound was cut away in Halaf times.

Judging from the artifactual evidence and some radiocarbon dates, the earliest levels that have so far been unearthed in the northeastern area closely resemble the basal strata found in the southeastern area and date from around 5300 B.C. The pottery from the earliest strata of occupation is again divided into various wares: Coarse, Fine, Gray-Black, and Darkfaced Burnished. In terms of vessel shape, the various wares closely resemble each other: most of the ceramics are characterized by convex, rounded bodies without a carination (carinated vessels seem to be characteristic for the Halaf strata of occupation) and closed rims with or without necks. Lug or loop handles are rather rare. Coarse ware is heavily predominant, comprising about $90 \%$ of the ceramic sample. These 
ceramics are vegetal-tempered, have thick walls, and are in most cases scraped and smoothed, although occasionally an overall burnish is perceptible (in about $20 \%$ of the Coarse ware sample). Sometimes a red slip is applied, or a rather roughly executed decoration (the most common kind of decoration consists of horizontal red-painted bands in combination with rows of combed impression). Fine ware lacks vegetal inclusions and is found in small quantities. Sometimes this pottery has a red slip (about 20\%) or painting. GrayBlack ware comprises a series of dark-colored ceramics, mostly mineral-tempered and with a fine paste. Usually the vessels have thin, burnished walls, occasionally carrying patterns of (sometimes white-filled) incisions (fig. 22: 67). Finally, some imported Darkfaced Burnished ware was found, with surface colors ranging from brown or red to gray or black. These ceramics contain rather large mineral inclusions and often have a burnished exterior, occasionally decorated by broad bands of dark red paint (these bands are sometimes burnished as well or combined with very thin patterns of incision; cf. fig. 22:66).

An interesting small find was a hematite stamp seal recovered from a pre-Halaf Neolithic stratum in trench U5. This rather large button seal has a perforated ridge handle and a carefully executed design of three groups of parallel-incised lines (fig. 11: 1). The center of the seal is both polished and slightly worn, perhaps due to intensive use. Fairly close parallels to this seal are found among the stamp seals of phase B and the First Mixed Range of the Amuq. ${ }^{35}$

In addition to the trenches in the northeastern part of Sabi Abyad, a series of test trenches $2 \mathrm{~m}$ wide and oriented north-south were laid out on the top of the site. These trenches revealed impressive remains of a monumental building dating from the late second millennium (the Late Bronze Age) and covering the lower, prehistoric strata. ${ }^{36}$ These prehistoric levels have not yet been reached in a well-defined, stratigraphic context. A test probe in one of the trenches yielded later Halaf pottery; apparently, early fifthmillennium strata can be found here, although they are deeply buried.

\section{CONCLUSIONS}

The recent archaeological work at Tell Sabi Abyad adds significantly to our understanding of local north-

\footnotetext{
${ }^{35}$ Braidwood and Braidwood (supra n. 3) 94-95, 12930 .

${ }^{36}$ Akkermans and Rossmeisl (supra n. 8).

${ }^{37}$ LeBlanc and Watson (supra n. 1) 117.

38 E.g., Davidson (supra n. 2) 341. Hijara (supra n. 1) 264;

T. Watkins and S. Campbell, "The Chronology of the Halaf
}

Syrian society of the later sixth millennium. The emphasis of research concerns the rise and development of Halaf culture, the "first widespread cultural horizon" 37 in the Near East but one that is still largely shrouded in mystery. A major result is undoubtedly the proof that in the Balikh region of north Syria the transition from the pre-Halaf Neolithic to the Early Halaf period was of a most gradual nature, and that Halaf represents a local development directly derived from earlier Neolithic cultural traditions in this area. No break in occupation was indicated, the major difference being the introduction of finely painted pottery in small but ever-increasing quantities from level 6 onward. In this respect, the prevailing view ${ }^{38}$ that the North Mesopotamian plain is the heartland of Halaf society and that Halaf spread from northern Iraq into the surrounding regions (including Syria) in the early fifth millennium can no longer be maintained: the Syrian Jezirah definitely forms part of the Halaf homelands. A series of radiocarbon dates from Sabi Abyad indicates that Halaf first appeared around $5200 / 5100$ B.C.; the often-mentioned figure of $7570 \pm 35$ B.P. (5620 B.C.) from Tell Halaf, said to date the transition from Altmonochrome to Halaf, ${ }^{39}$ is much too early and can safely be rejected. The rise of Halaf coincided with a series of changes in peopleand-land relationships, the most important of which were an increase in population (after a millennium or so of population decline) and a twofold development of both subsistence strategies and settlement organization, with, on the one hand, relatively large and permanently occupied agricultural settlements of long duration and, on the other hand, short-term, basically pastoral sites of a more mobile nature. ${ }^{40}$

Rather curious and unexpected is the outline of settlement at Sabi Abyad. Halaf villages are commonly viewed as relatively dense clusters of round buildings, but Sabi Abyad clearly points in the opposite direction: here the Early Halaf settlement was of a spacious layout, with isolated and multiroomed rectilinear buildings, surrounded on the slopes by both circular and rectangular auxiliary structures. For the site as a whole, one has to reckon with only four or five extended house units, accommodating perhaps only $30-$ 50 persons. Apparently, Sabi Abyad was hardly more than a hamlet despite its considerable size (the site is one of the largest later Neolithic sites in the Balikh

Culture," in O. Aurenche et al. eds., Chronologies in the Near East (Oxford 1987) 427-64.

39 J.C. Vogel and H.T. Waterbolk, "Groningen Radiocarbon Dates," Radiocarbon 6 (1964) 349-69.

40 Akkermans (supra n. 11). 
valley). Actually, this picture holds for most other sites in the region as well, and there can be little doubt that the Balikh drainage was sparsely populated in the later sixth millennium (an estimated population of 400-700 persons, judging from the small number of sites and restricted site size). ${ }^{41}$ In this respect it seems that any hierarchical ordering, both at the intra- and intersite level, was weakly developed. Social relationships must have been mainly based upon small-scale "egalitarian" family or kinship ties; decision-making primarily relied upon consensus rather than upon the exercise of power by formally sanctioned authorities. Additional support for this comes from the fact that indicators of "status" were rare (if not absent), that full-time segmental specialization seems to have been absent or only weakly developed, and that "public" institutions in a material sense seem to be lacking. ${ }^{42}$ In this sense, Early Halaf society in the Balikh region can be defined as "non-hierarchical" 43 and "tribal." 44

On the other hand, reciprocal socioeconomic dependence between the various communities will have existed at all levels, particularly among nearby settlements (as can be inferred from the widespread distribution of virtually identical painted ceramics and other cultural traits). Sabi Abyad may have fulfilled some kind of regional service function, perhaps as a marketplace distributing commodities and services over a considerable area. For example, there is some evidence that pottery was locally manufactured at Sabi Abyad and that it subsequently may have been transferred to small sites nearby, perhaps in exchange for food products or other domestic items. Moreover, Sabi Abyad, undoubtedly the ancestral community of various sites nearby (the site has a much longer history than its neighbors, most of which were newly founded in the Halaf period), may have acted as a center in a more spiritual sense, e.g., as the scene of marriage contracts, communal festivities, and ceremonies (perhaps the level 3 terrace served as a kind of ceremonial plaza). Particularly for the more mobile and pastoral components ${ }^{45}$ of local Halaf society moving around in a sparsely populated region, Sabi Abyad may have been a kind of landmark, existing since "time immemorial." For these mobile groups the site with its numerous storage facilities may also have been a focal storage and distribution point for cereals and other commodities, perhaps visited seasonally.

Around 5000 B.C. the prehistoric settlement on the southeastern mound of Sabi Abyad seems to have come to an end. Occupation contracted to the western half of the site, and ultimately Sabi Abyad was abandoned in the early fifth millennium. The cause of this apparent decline is not yet clear. In contrast, other Balikh sites experienced an excessive growth at this time, especially Tell Mounbatah in the central valley, now covering an area of perhaps 12 ha.

\author{
RAPENBURG 28 \\ P.O. BOX 11114 \\ 2301 EC LEIDEN \\ THE NETHERLANDS \\ MAISON DE L'ORIENT \\ UNIVERSITÉ LYON-2 \\ 7, RUE RAULIN \\ 69007 LYONS \\ FRANCE
}

NATIONAL MUSEUM OF ANTIQUITIES
${ }^{41}$ Akkermans (supra n. 11) 186-91.

${ }^{42}$ Cf. Akkermans (supra n. 11). Occasionally the tholoi are considered to be public buildings but hardly any sound evidence is found to support this view.

${ }^{43}$ It is stressed that "non-hierarchical" does not simply equal "egalitarian" but only that formal institutions of authority are absent. It can hardly be maintained that any human society is of an egalitarian nature; society is always constructed as a complex system of interdependencies and often subtle relations of dominance, which are regularized, maintained, and reproduced by recurrent social practices among individuals and groups. See A. Giddens, Central
Problems in Social Theory (London 1979); and C. Tilley, "Social Formation, Social Structures and Social Change," in I. Hodder ed., Symbolic and Structural Archaeology (Cambridge 1982) 26-38.

${ }_{44}$ M.D. Sahlins, Tribesmen (Englewood Cliffs 1968); E.R. Service, Primitive Social Organization (New York 1971). D.P. Braun and S. Plog, "Evolution of 'Tribal' Social Networks: Theory and Prehistoric North American Evidence," AmerAnt 47 (1982) 504-25.

45 For an account of Halaf mobility and pastoralism in the Balikh valley, see Akkermans (supra n. 11) 264-68. 